\title{
12. CENOZOIC DIATOM BIOSTRATIGRAPHY OF THE MIDDLE AMERICA TRENCH AND SLOPE, DEEP SEA DRILLING PROJECT LEG 84
}

\author{
Barbara Winsborough, Espey, Huston, and Associates, Inc., Geological Services, Austin \\ and \\ William H. Abbott, Mobil Exploration and Production Services, Inc., Dallas ${ }^{2}$
}

\begin{abstract}
Eocene to upper Pleistocene diatoms were recovered during DSDP Leg 84. The stratigraphic distributions of these diatoms at Sites 565 through 570 are presented. Published Zones of Burckle $(1972,1977,1978)$, Burckle and Trainer (1979), and Barron $(1980,1981,1983)$ for low-latitude Pacific biostratigraphy are recognized in these sediments, although certain zones are absent, owing to depositional hiatuses.
\end{abstract}

\section{INTRODUCTION}

Leg 84 began in Balboa, Panama and ended in Manzanillo, Mexico (January and February, 1982). One of the primary objectives of this cruise was to establish the age and structure of the continental framework that forms the landward slope of the Middle America Trench off Guatemala. Drilling at six sites cored through thick sedimentary sequences, and at four of these sites penetrated basement rock. Site 565 is on the lower slope off the Nicoya Peninsula of Costa Rica. The remainder of the sites lie along a transect across the landward side of the Middle America Trench off Guatemala (Fig. 1). The taxa referenced in this report are listed in the Appendix.

Diatomaceous intervals of primarily muds and mudstones dating back to the Eocene were recovered. None of the sections are complete; unconformities, probably resulting from the general instability of the slope, were recognized at every site.

Unconformities are most noticeable at the base of the Pleistocene and in the upper Miocene. Upper Pliocene sediments are absent at Sites 566 and 567. The entire Pliocene is missing at Site 568, and all but the uppermost Pliocene is missing from Site 569. Miocene hiatuses, particularly in the upper and middle part, are present at all sites where drilling penetrated material older than upper Miocene. Sediment thickness varies considerably from one site to another, suggesting that rates of accumulation or removal on the slope were very localized. For this reason, the hiatuses and periods of deposition cannot be correlated directly from one site to the next.

Some of Burckle's diatom zones (1972, 1977, 1978) are recognized in these sediments. There is generally a thick Pleistocene section present which contains the Pseudoeunotia doliolus and Nitzchia reinholdii zones. Rhi-

\footnotetext{
${ }^{1}$ von Huene, R., Aubouin, J., et al., Init. Repts. DSDP, 84: Washington (U.S. Govt. Printing Office).

2 Addresses: (Winsborough, present address) Dept. of Geological and Geophysical Sciences, Princeton University, Princeton, NJ 08540; (Abbott) Mobil Exploration and Production Services, Inc., P.O. Box 900, Dallas, TX 75221.
}

zosolenia praebergonii was very rare in these cores, but the $R$. praebergonii Zone could be detected at Sites 565 , 567,568 , and 570 .

The Nitzschia jouseae Zone and the Thalassiosira convexa Zone are recognized at Site 566 and in Hole 567A. The Nitzschia miocenica and Nitzschia porteri zones were absent entirely, but the next oldest zone, that of Coscinodiscus yabei, is recognized at Site 570. Figure 2 is a summary of the eastern equatorial Pacific diatom chronology of Burckle $(1972,1977)$.

\section{METHODS}

Core-catcher samples were collected from the bottom of each core recovered at the six sites on Leg 84 . Smear slides for immediate use were made from each of these samples. Some of the samples were also cleaned in hydrogen peroxide, potassium dichromate, and hydrochloric acid, as time permitted. This was done to concentrate particularly sparse or poorly preserved samples occurring at critical intervals during coring operations.

Additional samples-totaling 120 from Site 565, 26 from Site 566, 67 from Site 567, 198 from Site 568, 120 from Site 569, and 155 from Site 570-were collected on the ship and forwarded to the authors for shore-based study. These samples were cleaned with hydrogen peroxide and hydrochloric acid and mounted in Hyrax. The set of samples examined by Abbott was processed using a heavy-liquid density flotation method. This method was effective in concentrating the actual numbers of diatoms present in a sample, and in removing extraneous material.

The results of our analyses, representing the combined data of both authors, are presented in Tables 1 through 6 .

Not all species observed in the assemblages are included on the range charts. In keeping with the concept of the Initial Reports, this study focused on those diatom species considered to be biostratigraphically useful and helpful in characterizing the assemblage. All sampled intervals were examined by the authors. For brevity, those intervals not containing biostratigraphically useful taxa are not listed on the tables. When preservation was poor, some identifications were made on fragmental or eroded specimens, and must therefore be considered best guesses. The plates illustrate many of the useful and particularly common and interesting taxa observed during this study.

\section{RESULTS}

Tables 1 through 6 summarize the zonal and age assignments of diatomaceous sediments recovered during Leg 84 . We now discuss the diatom biostratigraphy of the individual Leg 84 sites. 


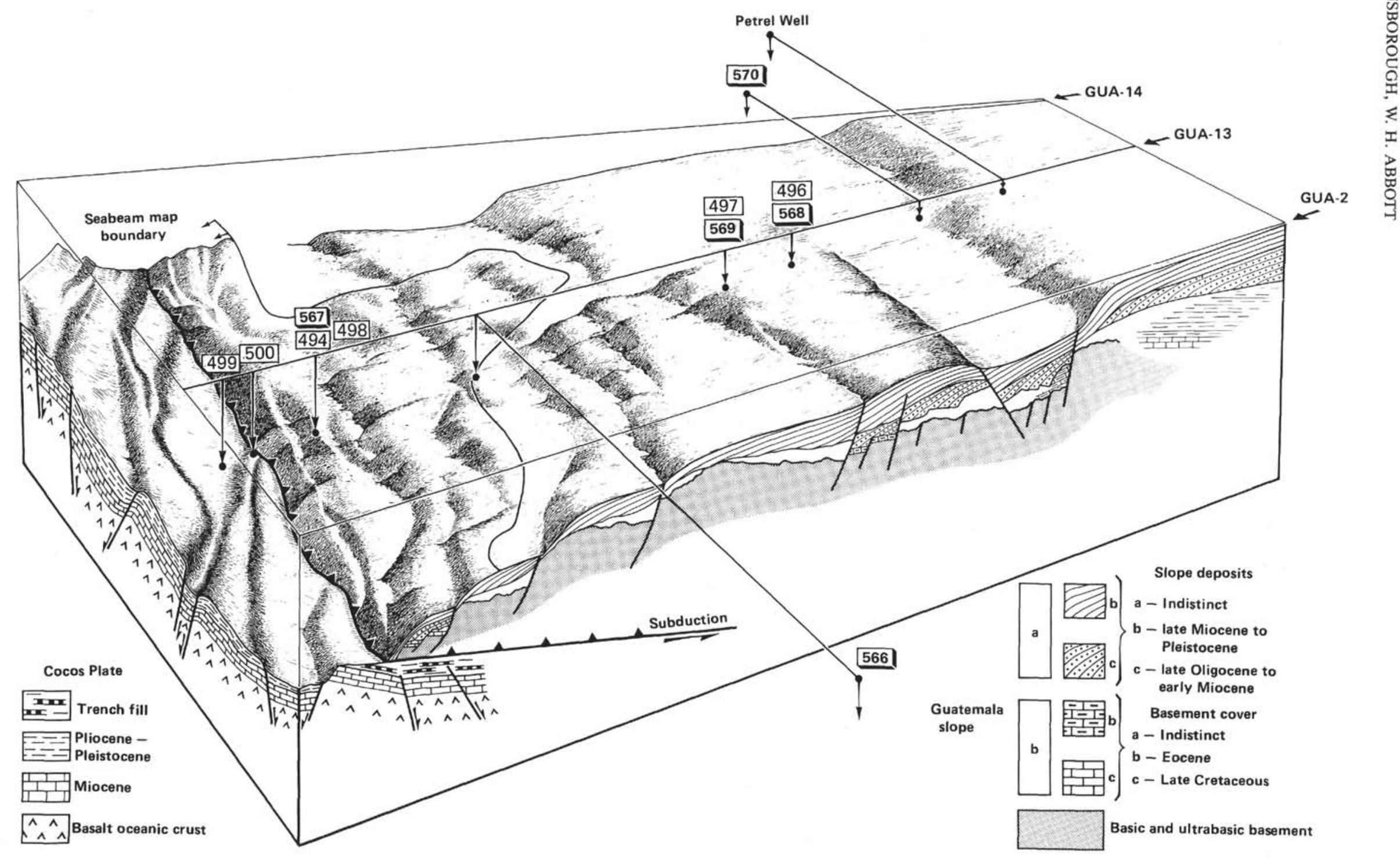

Figure 1. Locations of DSDP sites referred to in this chapter. 


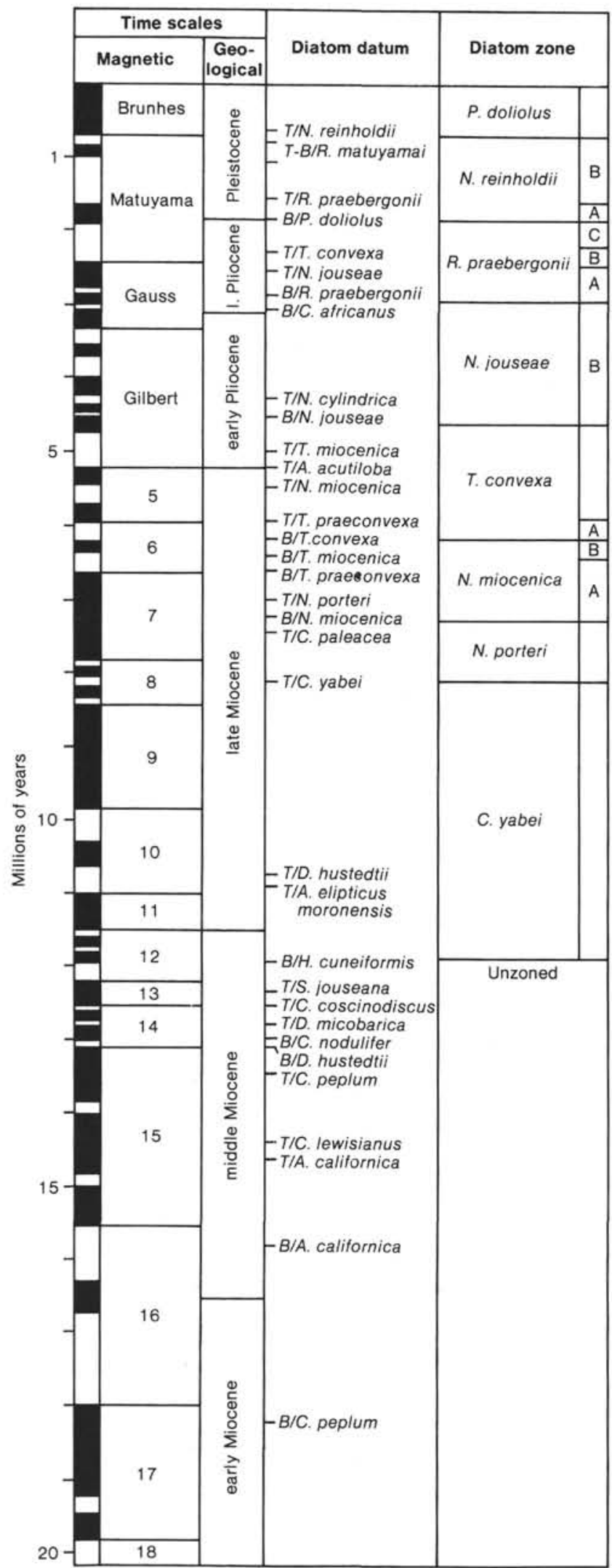

Figure 2. Eastern equatorial Pacific diatom zonation (from Harper et al., 1982; data from Burckle, 1972, 1977). T = top, B = base; shaded $=$ normal polarity, unshaded $=$ reversal polarity; $\mathrm{A}, \mathrm{B}$, and $\mathrm{C}=$ diatom subzones).

\section{Site 565}

Site 565 is on the lower slope off the Nicoya Peninsula of Costa Rica $\left(09^{\circ} 43.69^{\prime} \mathrm{N}, 86^{\circ} 05.44^{\prime} \mathrm{W}\right)$. The single hole was drilled in $3111 \mathrm{~m}$ of water to $328 \mathrm{~m}$ sub-bottom. The site is about $20 \mathrm{~km}$ landward of the Middle America Trench axis, on a small, raised intercanyon area between two deep submarine canyons.

In the 34 cores recovered, the major lithology of most of the sequence is a homogeneous dark green to olivegray mud and mudstone. Two thin layers of sandstone and several ash layers were recovered.

The diatoms at Site 565 , in contrast with those at the other five sites, are generally rare and poorly preserved. If diatom production occurred at this site, downslope sediment transport, slumping, and extensive bioturbation, possibly coupled with chemical dissolution, have obscured their remains.

Selected diatom occurrences at this site are summarized in Table. 1.

The oldest diatoms that could be assigned to a zone were found in Core 565-19. Below this core, only the long-ranging species Thalassionema nitzschioides, Ethmodiscus rex, Actinocyclus octonarius, Coscinodiscus marginatus, Melosira granulata, Paralia sulcata, and Triceratium cinnamomeum were recorded. Thalassiosira convexa, a diatom indicative of the $T$. convexa Zone (Burckle, 1972), was observed in 565-19,CC. The interval from Core $565-18$ to $565-16, C C$ was barren, so no estimate of its age is possible.

The first occurrence of Rhizosolenia praebergonii in 565-16, CC as well as the first occurrence of Pseudoeunotia doliolus in 565-8, CC define this interval (565-8,CC to $565-16, \mathrm{CC})$ as the Rhizosolenia praebergonii Zone (Burckle, 1972). This interval also contained fragments of much older diatoms reworked into the sediment.

The Nitzschia reinholdii Zone ranges upsection from the first occurrence of $P$. doliolus $(565-8, \mathrm{CC})$ to the ex-

Table 1. Stratigraphic occurrences of selected diatoms in Hole 565.

\begin{tabular}{|c|c|c|c|c|c|c|c|c|c|c|}
\hline Subseries & $\begin{array}{l}\text { Diatom } \\
\text { zone }\end{array}$ & $\begin{array}{c}\text { Sample } \\
\text { (interval in } \mathrm{cm} \text { ) }\end{array}$ & 尊 & 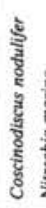 & & 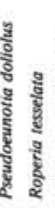 & $\begin{array}{l}\text { है } \\
\text { है } \\
\text { है } \\
\frac{\text { g. }}{3} \\
\frac{3}{3} \\
\frac{3}{5} \\
\text { है }\end{array}$ & 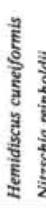 & 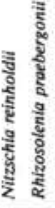 & 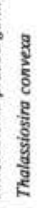 \\
\hline $\begin{array}{c}\text { upper } \\
\text { Pleistocene }\end{array}$ & $\begin{array}{c}\text { Pseudoeunotia } \\
\text { doliolus }\end{array}$ & $1-1,20-21$ and $24-25$ & G & R & R F & R F & c & & & \\
\hline $\begin{array}{c}\text { lower } \\
\text { Pleistocene }\end{array}$ & $\begin{array}{l}\text { Nitzschia } \\
\text { reinholdii }\end{array}$ & $\begin{array}{l}1-2,50-51 \text { and } 52-53 \\
1-4,69-70 \text { and } 70-71 \\
1, C C \\
2-3,33-34 \text { and } 76-77 \\
2-4,27-28 \text { and } 33-34 \\
2, C C \\
3, C C \\
4, C C \\
7-2,21-22 \text { and } 25-26 \\
7, C C \\
8-4,16-17 \text { and } 35-36 \\
8, C C\end{array}$ & $\begin{array}{l}\mathrm{G} \\
\mathrm{G} \\
\mathrm{G}-\mathrm{M} \\
\mathrm{G} \\
\mathrm{G}-\mathrm{M} \\
\mathrm{G}-\mathrm{M} \\
\mathrm{P} \\
\mathrm{P} \\
\mathrm{P} \\
\mathrm{P} \\
\mathrm{P} \\
\mathrm{P}\end{array}$ & $\begin{array}{l}\mathrm{C} \\
\mathrm{C} \\
\mathrm{C} \\
\mathrm{C} \\
\mathrm{C} \\
\mathrm{C} \\
\mathrm{R} \\
\mathrm{R} \\
\mathrm{R} \\
\mathrm{R} \\
\mathrm{R} \\
\mathrm{R}\end{array}$ & $\begin{array}{lll}R & \\
R & \\
R & \\
R & \\
R & \\
C & \\
& \\
& \\
R & \\
R\end{array}$ & $\begin{array}{ll}\mathrm{R} & \\
\mathrm{R} & \\
\mathrm{R} & \\
\mathrm{R} & \mathrm{R} \\
\mathrm{R} & \mathrm{R} \\
\mathrm{F} & \\
\mathrm{R} & \\
\mathrm{R} & \\
\mathrm{R} & \\
\mathrm{R} & \end{array}$ & $\begin{array}{l}\mathrm{C} \\
\mathrm{C} \\
\mathrm{F} \\
\mathrm{C} \\
\mathrm{R} \\
\mathrm{C} \\
\mathrm{R} \\
\mathrm{R} \\
\mathrm{R} \\
\mathrm{R} \\
\mathrm{R}\end{array}$ & $\begin{array}{ll}C & R \\
& \\
R & R \\
R & R \\
R & R \\
& R \\
& R\end{array}$ & $\begin{array}{l}\mathbf{R} \\
\begin{array}{l}\mathrm{R} \\
\mathrm{R} \\
\mathrm{R} \\
\mathrm{R}\end{array}\end{array}$ & \\
\hline $\begin{array}{c}\text { upper } \\
\text { Pliocene }\end{array}$ & $\begin{array}{l}\text { Rhizosolenia } \\
\text { praebergonii }\end{array}$ & $\begin{array}{l}13 \cdot 2,79-80 \text { and } 80-81 \\
13 \cdot 4,79-80 \text { and } 80-81 \\
13, C C \\
16, C C\end{array}$ & $\begin{array}{l}\mathrm{M}-\mathrm{P} \\
\mathrm{P} \\
\mathrm{F}-\mathrm{P} \\
\mathrm{F}\end{array}$ & $\begin{array}{l}\mathbf{R} \\
\mathbf{R} \\
\mathbf{F}\end{array}$ & & & & $\begin{array}{l}R \\
R\end{array}$ & & R \\
\hline $\begin{array}{l}\text { pper Miocene- } \\
\text { ower Pliocene }\end{array}$ & & $19, \mathrm{CC}$ & P & & & & & & & R \\
\hline
\end{tabular}

Note: $\mathrm{C}=$ common, $\mathrm{F}=$ few, $\mathrm{R}=$ rare. Preservation: $\mathrm{G}=$ good, $\mathrm{M}=$ moderate, $\mathrm{P}=$ poor. Blank means taxon is absent. 
tinction of $N$. reinholdii (Section 565-1-2). Burckle (1977) assigns an age of approximately 630,000 yrs. to the last occurrence of $N$. reinholdii. The youngest zone recognizable at Site 565 is the $P$. doliolus Zone (Burckle, 1977), whose base is placed immediately above the last appearance of $N$. reinholdii. A modern flora is present throughout this zone.

\section{Site 566}

Site 566 includes Holes $566\left(12^{\circ} 48.34^{\prime} \mathrm{N}, 90^{\circ} 41.79^{\prime} \mathrm{W}\right)$, $566 \mathrm{~A}\left(12^{\circ} 47.91^{\prime} \mathrm{N}, 90^{\circ} 41.99^{\prime} \mathrm{W}\right), 566 \mathrm{~B}\left(12^{\circ} 48.81^{\prime} \mathrm{N}\right.$, $\left.90^{\circ} 41.50^{\prime} \mathrm{W}\right)$, and $566 \mathrm{C}\left(12^{\circ} 48.84^{\prime} \mathrm{N}, 90^{\circ} 41.53^{\prime} \mathrm{W}\right)$. This site is about $100 \mathrm{~km}$ off Guatemala, about two-thirds of the way down the slope of the Middle America Trench and about $25 \mathrm{~km}$ northeast of the trench axis. The holes were drilled in 3745,3846 , and $3661 \mathrm{~m}$ of water, respectively. (Hole 566B had no recovery). Drilling at Hole 566 penetrated $55.8 \mathrm{~m}$ sub-bottom, recovering 9 cores; at Hole $566 \mathrm{~A}, 7 \mathrm{~m}$, recovering 1 core; and at Hole $566 \mathrm{C}$, $136.6 \mathrm{~m}$, recovering 7 cores. The main objective at this site was to identify the lithology of the oldest slope deposits and of the acoustic basement underlying the sediments. Hole 566 was drilled though a generally uniform upper Pleistocene lithology of dark olive-gray mud with graded sandstone beds and silty laminations. Pebbles of mudstone, pyrite, and serpentinite were also observed in the sediment. Below this was weathered serpentinite. In Hole 566A, the first $6 \mathrm{~m}$ of sediment was dark greenish gray siliceous Pliocene mud resting directly on basement. In Hole $566 \mathrm{C}$, the first $50 \mathrm{~m}$ of sediment was washed out and 4 cores were drilled through dark olive-gray mud, mudstone, and sandstone (upper Miocene).

Stratigraphic occurrences of selected diatoms at Site 566 are summarized in Table 2.
The oldest diatomaceous material occurs in Section 566C-2-1. The assemblage contains several species that made their evolutionary appearances at the end of the Miocene and ranged throughout most of the Pliocene, including Thalassiosira oestrupii, Rossiella tatsunokuchiensis, Nitzschia reinholdii, and Thalassiosira convexa. The interval from Section 566C-2-1 to the top of Hole $566 \mathrm{C}$ is therefore assigned to the T. convexa Zone, on the basis of the presence of $T$. convexa and the absence of Nitzschia jouseae.

Sample 566C-1,CC (the only sample recovered from Hole $566 \mathrm{C}$ ) is assigned to the Nitzschia jouseae Zone, on the basis of the occurrence of $N$. jouseae without Rhizosolenia praebergonii.

A barren interval exists from the base of Hole 566 (Core 9) to Section 566-5-2, where 12 diatom species were observed. The occurrence together of Pseudoeunotia doliolus, Rhizosolenia praebergonii, and Nitzschia reinholdii indicates the lower Pleistocene for the section from Section 566-5-2 to Section 566-2-4, assigned to the $N$. reinholdii Zone. The interval from the last appearance of $N$. reinholdii in 566-2-4 to the top of the core is within the Pseudoeunotia doliolus Zone.

\section{Site $\mathbf{5 6 7}$}

Site 567, which includes Holes $567\left(12^{\circ} 42.96^{\prime} \mathrm{N}, 90^{\circ}\right.$ $\left.55.99^{\prime} \mathrm{W}\right)$ and $567 \mathrm{~A}\left(12^{\circ} 42.99^{\prime} \mathrm{N}, 90^{\circ} 55.92^{\prime} \mathrm{W}\right)$, is situated off Guatemala at the base of the lower slope, 3 to $5 \mathrm{~km}$ upslope from the floor of the Middle America Trench, in $5500 \mathrm{~m}$ of water. Only 2 cores were recovered at Hole 567 , although the drilling penetrated $195.5 \mathrm{~m}$ of sediment. Twenty-nine cores were recovered from Hole $567 \mathrm{~A}$, representing a penetration of $501 \mathrm{~m}$. Serpentinite was observed in Cores 567A-7 and 567A-14 to 567A-18.

Table 2. Stratigraphic occurrences of selected diatoms in Holes 566, 566A, and 566C.

\begin{tabular}{|c|c|c|c|c|c|c|c|c|c|c|}
\hline Subseries & $\begin{array}{l}\text { Diatom } \\
\text { zone }\end{array}$ & $\begin{array}{c}\text { Sample } \\
\text { (interval in } \mathrm{cm} \text { ) }\end{array}$ & 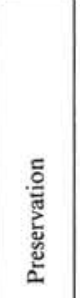 & 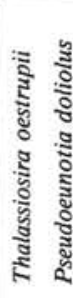 & 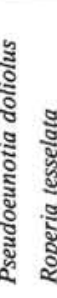 & 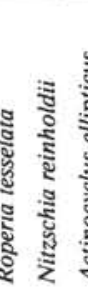 & 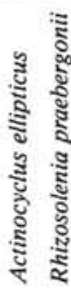 & 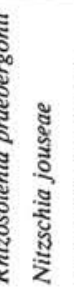 & 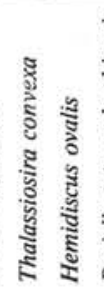 & 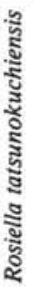 \\
\hline $\begin{array}{c}\text { upper } \\
\text { Pleistocene }\end{array}$ & $\begin{array}{l}\text { Pseudoeunotia } \\
\quad \text { doliolus }\end{array}$ & $\begin{array}{l}\text { Hole 566 } \\
1-2,22-23 \text { and } 32-33 \\
1, C C \\
2-2,23-24 \\
2-3,14-15\end{array}$ & $\begin{array}{l}G \\
G \\
G\end{array}$ & $\begin{array}{ll}\mathrm{F} & \mathrm{R} \\
\mathrm{C} & \mathrm{F} \\
\mathrm{R} & \mathrm{R} \\
\mathrm{C} & \mathrm{C}\end{array}$ & $\begin{array}{ll}R & R \\
F & \\
R & \\
C & R\end{array}$ & & & & & \\
\hline $\begin{array}{c}\text { lower } \\
\text { Pleistocene }\end{array}$ & $\begin{array}{l}\text { Nitzschia } \\
\text { reinholdii }\end{array}$ & $\begin{array}{l}2-4,14-15 \text { and } 23-24 \\
2, C C \\
3, C C \\
4-2,48-49 \text { and } 53-54 \\
4, C C \\
5-2,29-30 \text { and } 77-78\end{array}$ & $\begin{array}{l}\text { G } \\
M \\
G \\
G \\
G \\
G\end{array}$ & $\begin{array}{ll}\mathrm{C} & \mathrm{C} \\
\mathrm{R} & \mathrm{F} \\
\mathrm{R} & \mathrm{C} \\
\mathrm{F} & \mathrm{R} \\
\mathrm{A} & \mathrm{F} \\
\mathrm{R} & \mathrm{R}\end{array}$ & $\begin{array}{l}C \\
F \\
C \\
R \\
F \\
R\end{array}$ & $\begin{array}{ll}\text { R } & \text { R } \\
\text { R } & \text { F } \\
\text { R } & \\
\text { R } & \text { F } \\
& \text { F }\end{array}$ & $\begin{array}{ll}\mathrm{R} & \\
\mathrm{R} & \mathrm{R} \\
& \mathrm{R} \\
\mathrm{F} & \\
\mathrm{R} & \mathrm{R}\end{array}$ & R & & \\
\hline $\begin{array}{c}\text { upper } \\
\text { lower } \\
\text { Pliocene }\end{array}$ & $\begin{array}{l}\text { Nitzschia } \\
\text { jouseae }\end{array}$ & $\begin{array}{l}\text { Holes } 566 \mathrm{~A}, 566 \mathrm{C} \\
566 \mathrm{~A}-1, \mathrm{CC} \\
566 \mathrm{C}-1, \mathrm{CC}\end{array}$ & $\begin{array}{l}\text { M-P } \\
P\end{array}$ & R & & R $\mathrm{F}$ & $\mathrm{F}$ & $\begin{array}{l}\mathrm{F} \\
\mathrm{R}\end{array}$ & $\begin{array}{lll}\mathrm{R} & & \\
\mathrm{R} & \mathrm{R}\end{array}$ & R \\
\hline $\begin{array}{l}\text { upper Miocene- } \\
\text { lower Pliocene }\end{array}$ & $\begin{array}{l}\text { Thalassiosira } \\
\text { convexa }\end{array}$ & $566 \mathrm{C}-2-1,9-10$ & $\mathbf{P}$ & & & F & & & $\mathrm{F}$ & F \\
\hline
\end{tabular}

Note: See Table 1 for explanation of abbreviations. 
Basement (Cores 567A-20 through 567A-29) is composed of gabbro, diabase, basalt, and serpentine.

Selected diatom occurrences at this site are listed in Table 3.

Pleistocene through lower Pliocene lithology is a dark olive-gray siliceous mud unconformably overlying grayish olive to dusky yellowish green Miocene muds with sedimentary breccias and boulders. On the basis of the other fossil disciplines, limestone clasts (Eocene) and nannofossil ooze clasts (Cretaceous) are present in Cores 12,13 , and 18 of Hole 567A (Filewicz, this volume). Evidence of bioturbation is common throughout the sediments at this site. Core 567A-18 contained clasts with the Eocene Archaeomonas dubia $(567 \mathrm{~A}-18, \mathrm{CC})$ and $\mathrm{Mo}$ nobrachia simplex (Section 567A-18-1). These clasts were embedded in a mud matrix with lower middle Miocene Craspedodiscus coscinodiscus, suggesting that the clasts are upper lower to lower middle Miocene.

The next diatomaceous interval, from 567A-13,CC to Core 567A-10, contains a mixed assemblage of well-preserved Rocella vigilans (Oligocene), Trinacria excavata (Cretaceous-Eocene), Rossiella veniamini (lower Miocene), and Craspedodiscus coscinodiscus (lower to lower middle Miocene). This interval is assigned to the upper lower Miocene, on the basis of the absence of any taxa restricted to the middle Miocene or younger. Support for this assignment comes from nannofossil evidence, which places Cores 567A-13 through 567A-3,CC in the lower Miocene (Filewicz, this volume). In the interval from Section 567A-10-4 through Section 567A-3-6, taxa which evolved in the middle Miocene-Actinocyclus ellipticus, Coscinodiscus nodulifer, Actinocyclus ingens, and Hemidiscus cuneiformis - were observed. Synedra jouseana was also observed, and we assign this interval to the upper middle Miocene on the basis of the range of that species. This is in disagreement with nannofossil determinations (Filewicz, this volume), which place this interval in the lower Miocene. The occurrence together of $H$. cuneiformis and $S$. jouseana differs from the range reported by Burckle (1978), although Burckle now has data (pers. comm., 1982) placing the first appearance of $H$. cuneiformis and the last appearance of $S$. jouseana together in Epoch 12.

Sample 567A-3-2, 74-75 cm is assigned to the T. convexa Zone on the basis of the disappearance of $S$. jouseana and the appearance of $T$. convexa. The interval from 567A-2, CC to the top of Hole 567A is assigned to the $N$. jouseae Zone, on the basis of the presence of Rossiella tatsunokuchiensis throughout this interval. A hiatus represented by the absence of the $R$. praebergonii Zone is indicated between the bottom of Hole 567 and the top of Hole 567A. A similar hiatus was noticed on Leg 67, Site 496, where Harper et al. (1982) remarked on the absence of Rhizosolenia praebergonii at the base of the Pleistocene. The interval from 567-2, CC to 5671,CC represents the Nitzschia reinholdii Zone.

Table 3. Stratigraphic occurrences of selected diatoms in Holes 567 and 567A.

\begin{tabular}{|c|c|c|c|c|c|c|c|c|c|c|c|c|}
\hline Subseries & $\begin{array}{l}\text { Diatom } \\
\text { zone }\end{array}$ & $\begin{array}{c}\text { Sample } \\
\text { (interval in } \mathrm{cm} \text { ) }\end{array}$ & 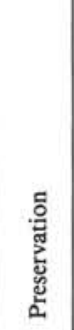 & 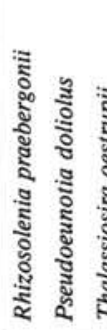 & 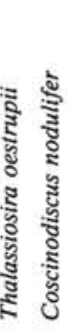 & 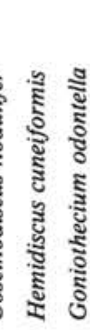 & 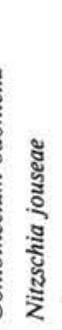 & 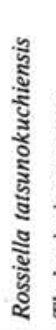 & 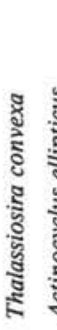 & 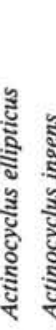 & 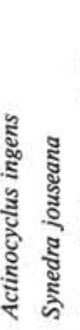 & 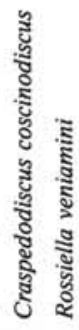 \\
\hline $\begin{array}{c}\text { lower } \\
\text { Pleistocene }\end{array}$ & $\begin{array}{l}\text { Nitzschia } \\
\text { reinholdii }\end{array}$ & $\begin{array}{l}\text { Hole } 567 \\
1, \mathrm{CC} \\
2, \mathrm{CC}\end{array}$ & $\begin{array}{l}\text { M-P } \\
\text { G-M }\end{array}$ & $\begin{array}{lll}\mathbf{R} & \mathbf{R} \\
\mathrm{R} & \mathrm{C} & \end{array}$ & $\begin{array}{ll}\mathrm{F} & \mathrm{R} \\
\mathrm{C} & \mathrm{R}\end{array}$ & $\begin{array}{l}R \\
R\end{array}$ & & & & R & & \\
\hline $\begin{array}{l}\text { middle and } \\
\text { upper lower } \\
\text { Pliocene }\end{array}$ & $\begin{array}{l}\text { Nitzschia } \\
\text { jouseae }\end{array}$ & $\begin{array}{l}\text { Hole 567A } \\
1-4,37-38 \text { and } 47-48 \\
1-6,37-38 \\
1, C C \\
2-2,71-72 \\
2-3,50-51 \\
2-5,50-51 \\
2, \text { CC }\end{array}$ & $\begin{array}{l}\mathrm{P} \\
\mathrm{P} \\
\mathrm{P} \\
\mathrm{G} \\
\mathrm{M} \\
\mathrm{M} \\
\mathrm{M}\end{array}$ & & $\begin{array}{ll}F & R \\
R & \\
R & \\
F & F \\
R & R \\
R & R \\
F & R\end{array}$ & $\begin{array}{ll} & R \\
& R \\
& R \\
R \\
R \\
R \\
R\end{array}$ & $\begin{array}{l}R \\
R \\
R \\
R\end{array}$ & $\begin{array}{l}\mathrm{F} \\
\\
\mathrm{R} \\
\mathrm{F} \\
\mathrm{C}\end{array}$ & $\begin{array}{l}\mathrm{F} \\
\mathrm{R} \\
\mathrm{R} \\
\mathrm{F} \\
\mathrm{C} \\
\mathrm{R} \\
\mathrm{F}\end{array}$ & $\mathbf{R}$ & & \\
\hline $\begin{array}{l}\text { upper Miocene- } \\
\text { lower Pliocene }\end{array}$ & $\begin{array}{c}\text { Thalassiosira } \\
\text { convexa }\end{array}$ & $3-2,74-75$ and $91-92$ & M & & F & 7 & & & F & & & \\
\hline $\begin{array}{l}\text { middle } \\
\text { Miocene }\end{array}$ & Indeterminate & $\begin{array}{l}3-6,74-75 \\
4-2,21-22 \text { and } 77-78 \\
7-2,11-12 \text { and } 13-14 \\
8-2,66-67 \text { and } 80-81 \\
9-2,71-72 \text { and } 89-90 \\
10-2,30-31 \text { and } 69-70 \\
10-4,30-31 \text { and } 69-70 \\
10, C C\end{array}$ & $\begin{array}{l}\mathrm{P} \\
\mathrm{P} \\
\mathrm{M}-\mathrm{P} \\
\mathrm{P} \\
\mathrm{P} \\
\mathrm{P} \\
\mathrm{M} \\
\mathrm{P}\end{array}$ & & $\begin{array}{l}\mathbf{R} \\
\mathbf{R}\end{array}$ & $\begin{array}{l}R \\
R\end{array}$ & & $\mathbf{R}$ & & R R & $\begin{array}{ll} & R \\
& R \\
R & R \\
& R \\
R & \\
& \\
& R\end{array}$ & $\begin{array}{l}\mathrm{R} \\
\mathrm{R} \\
\mathrm{R} \\
\mathrm{F} \\
\mathrm{F}\end{array}$ \\
\hline $\begin{array}{l}\text { lower } \\
\text { Miocene }\end{array}$ & Indeterminate & $\begin{array}{l}12-4,79-80 \text { and } 89-90 \\
12, C C \\
13, C C\end{array}$ & $\begin{array}{l}\mathrm{P} \\
\mathrm{P} \\
\mathrm{P}\end{array}$ & & & & & . & & & & $\begin{array}{ll}\mathrm{R} & \\
\mathrm{R} & \mathrm{R} \\
\mathrm{R} & \mathrm{R}\end{array}$ \\
\hline
\end{tabular}

Note: See Table 1 for explanation of abbreviations. 


\section{Site 568}

Site $568\left(13^{\circ} 04.33^{\prime} \mathrm{N}, 90^{\circ} 48.00^{\prime} \mathrm{W}\right)$ is on the upper part of the Middle America Trench in about $2010 \mathrm{~m}$ of water. Forty-four cores were collected in $418 \mathrm{~m}$ of sediment.

Selected diatom occurrences at Site 568 are given in Table 4.

The oldest diatomaceous material at this site was recovered from 568-43,CC, which contained the lower to middle Miocene Synedra jouseana. The interval from Section 568-43-2 through Section 568-43-2 comprises a diatom-rich section containing a number of species restricted to the lower Miocene, including Actinocyclus radionovae, Rossiella veniamini, Cestodiscus pulcellus, Coscinodiscus oligocenicus, Craspedodiscus rydei, Coscinodiscus rhombicus, and Rossiella paleacea. This interval is therefore assigned to the lower Miocene Rossiella veniamini to Denticulopsis nicobarica zones of Barron (1983). Stephanopyxis grunowii, a species discussed by Hajos (1975), ranging from the Eocene to the middle Miocene, was present from Section 568-43-2 to Section 568-26-4.

Section 568-35-2 is assigned to the lower middle Miocene Cestodiscus peplum datum of Barron (1983) on the basis of the abundant occurrence of Coscinodiscus lewisianus and C. peplum and the disappearance of all lower Miocene taxa. Fragments of reworked Asterolampara praemarylandica (Oligocene) are also common, indicating some reworking. Middle to upper Miocene species characterize the interval from Cores 568-26 through 568-23. Annellus californicus (lower middle Miocene) was observed throughout most of this interval. Barron (1981) found a recurrence of $A$. californicus in the upper middle Miocene of the eastern equatorial Pacific, which may correlate with our observation. It is, however, also a robust form which withstands reworking. Rhizosolenia miocenica, restricted to the middle to upper Miocene (Schrader and Fenner, 1976), was recovered in Section 568-25-4.

Section 568-22-6 is assigned to the upper Pliocene, on the basis of well-preserved Rhizosolenia praebergonii as well as Hemidiscus aff. H. ovalis and Rossiella tatsunokuchiensis (common in 568-22,CC).

The lower Pleistocene guide fossils Pseudoeunotia doliolus and Nitzschia reinholdii were present at the base of Core 568-20. The interval from 568-20,CC through Core 568-15 represents the $N$. reinholdii Zone. In 568$15, \mathrm{CC}$, the short-ranging diatom Rhizosolenia matuyami was observed. Burckle (1978) described this taxon as a stratigraphically useful diatom in the middle Pleistocene, where the species ranges consistently from just below the Jaramillo to the lower part of the Jaramillo. This species was also described from Leg 67, Site 497 (Harper et al., 1982), where the $N$. reinholdii Zone began with Core 497-24 and $R$. matuyami was recorded from Core 497-17. The interval from the extinction of $N$. reinholdii in Section 568-15-2 to the top of the section at Site 568 is assigned to the $P$. doliolus Zone.

Harper et al. (1982) described the diatom biostratigraphy of Leg 67 Sites 495, 496, and 497. Site 496 is in the same general position as Site 568 , and Site 497 is near Site 569. These authors also refer to the biostratigraphic work of Burckle $(1972,1977,1978)$ and Barron (1980).

\section{Site 569}

Site 569, comprising Holes $569\left(12^{\circ} 56.31^{\prime} \mathrm{N}, 90^{\circ}\right.$ $\left.50.35^{\prime} \mathrm{W}\right)$ and $569 \mathrm{~A}\left(12^{\circ} 56.22^{\prime} \mathrm{N}, 90^{\circ} 50.81^{\prime} \mathrm{W}\right)$, is 125 $\mathrm{km}$ south of the Guatemala coast between Sites 567 and 568. The holes were drilled in about $2800 \mathrm{~m}$ of water, $32 \mathrm{~km}$ from the Middle America Trench axis, in the middle of the slope. At Hole 569, 27 cores were drilled through $250.7 \mathrm{~m}$ of sediment, and at Hole 569A, 11 cores were drilled through $364.9 \mathrm{~m}$ of sediment.

Pleistocene sediments in Hole 569 are dark olive-gray mud with about twelve ash layers. Miocene sediments overlying an unconformity are olive-gray muds and mudstones with small silty and sandy horizons.

Hole 569A yielded the oldest sediment recovered at this site. After washing down to $246 \mathrm{~m}$, coring was resumed in Oligocene and Eocene mudstone until basement of gabbro, amphibolite, and greenschist was encountered. Numerous ash layers and pumice clasts, and evidence of bioturbation, mottling, and fracturing, were common in various parts of the section.

Some diatom occurrences at this site are summarized in Table 5 .

The oldest diatomaceous interval encountered in Hole $569 \mathrm{~A}$ occurs in 569A-9, CC and 569A-11,CC. Present in limestone layers of this interval were the upper Eocene diatom species Monobrachia simplex, Hemiaulus polymorphus, and the archaeomonad Archaeomonas dubia.

Above a long barren interval from Core 569A-8 to Core 569A-3, diatoms were again encountered in 569A2,CC, 569A-1, CC, 569A-1-2, 30-31 cm, and 569A-1-2, $39-40 \mathrm{~cm}$.

The species in this interval from $2, \mathrm{CC}$ to $1-2,30-31$ $\mathrm{cm}$ included Rocella vigilans, restricted to the upper Oligocene, and lower Miocene taxa Coscinodiscus rhombicus and Actinocyclus radionovae. This interval is therefore assigned to the upper Oligocene-lower Miocene.

The studies of Hajos (1975) on the upper Eocene and lower Oligocene diatoms (Leg 29), the Oligocene work of Jousé (1974), and the work of Schrader and Fenner (1976), which included Eocene diatoms from Leg 38, were helpful in these lower intervals.

Lower Miocene taxa such as A. radionovae, Coscinodiscus lewisianus, Synedra jouseana, Coscinodiscus aff. C. oblongus, and Cestodiscus pulcellus were also characteristic of the lower part of Hole 569, in the interval from Core 569-27 to Core 569-23. Between Sections 569-23-4 and 569-13-4, a barren interval ensued. Section 569-13-4 contained the first occurrence of Actinocyclus ellipticus, which evolved in the middle Miocene (Barron, 1981). Other species characteristic of the lower to middle Miocene that are present in the interval from Core 569-13 through Core 569-10 include Craspedodiscus coscinodiscus, Actinocyclus radionovae, Coscinodiscus lewisianus, Synedra jouseana, Denticulopsis kanayae, Annellus californicus, and Coscinodiscus oblongus. This interval is therefore assigned to the upper lower to lower 
Table 4. Stratigraphic occurrences of selected diatoms in Hole 568.

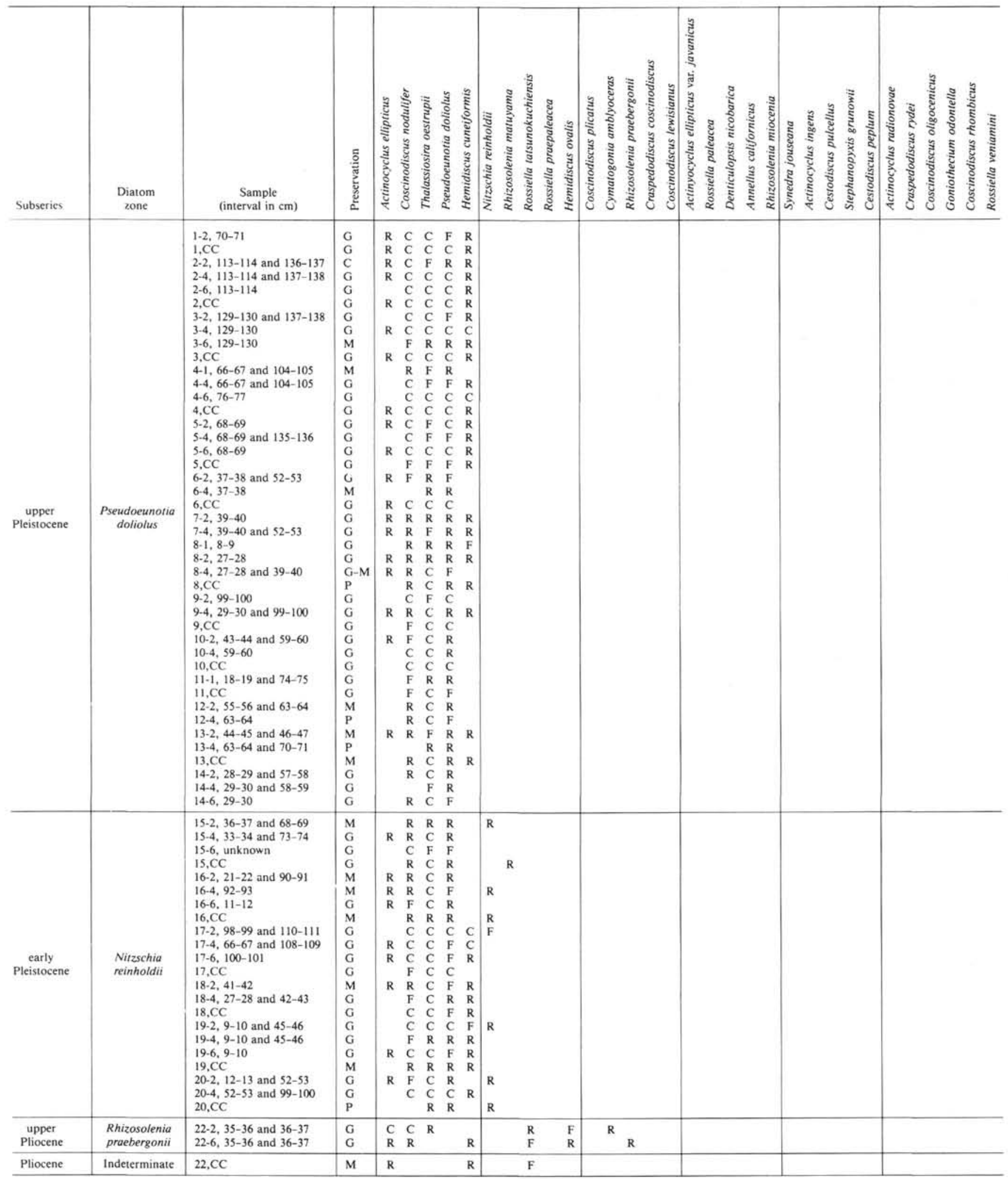


Table 4. (Continued).

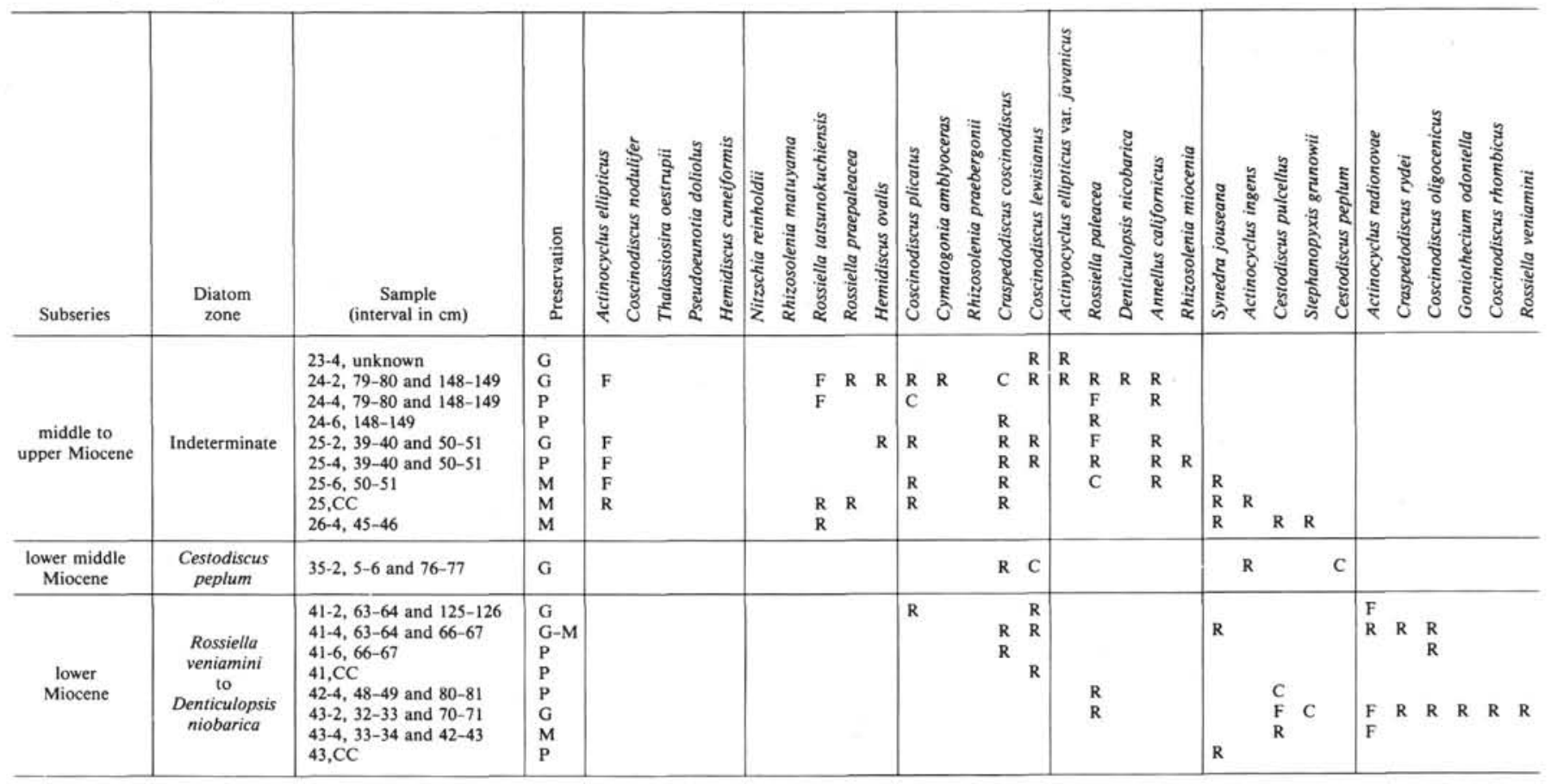

Note: See Table I for explanation of abbreviations.

middle Miocene. Reworking of older taxa was evident throughout this interval. For example, Asterolampara praemarylandica was observed in Core 569-10. This species is restricted to the lower to middle Oligocene in the tropical Pacific (Jousé, 1974).

There were insufficient stratigraphically useful diatoms in Core 569-9 to determine an age or demonstrate the presence of a hiatus, but 569-8,CC contained the Pliocene taxon Thalassiosira oestrupii, as well as the first occurrence of Thalassiosira convexa. Section 569-7,CC also contained frequent $T$. convexa. Core $569-8$ and the bottom of Core 569-7 are therefore assigned to the Thalassiosira convexa Zone. A hiatus apparently follows in the lower part of Core 569-7. Missing is at least part of the Pliocene, including the Nitzschia jouseae and Rhizosolenia praebergonii Zones.

Section 569-7-4 is assigned to the Nitzschia reinholdii Zone on the basis of the abundance of Pseudoeunotia doliolus. This zone extends to Section 569-4-2, where a modern flora characteristic of the $P$. doliolus Zone, including Roperia tesselata, is present.

\section{Site 570}

Site $570\left(13^{\circ} 17.12^{\prime} \mathrm{N}, 91^{\circ} 23.57^{\prime} \mathrm{W}\right)$ is $70 \mathrm{~km}$ south of the Guatemala coast, on a small bench in the upper-slope region of the Middle America Trench, about $40 \mathrm{~km}$ north of the trench axis. Water depth is about $1700 \mathrm{~m}$. Forty-two cores were collected, with a total penetration of $402 \mathrm{~m}$.

Pleistocene sediment lithology includes massive olivegray bioturbated mud and sand with numerous distinct ash layers and thin sand beds. The Pliocene sediment is similar but harder, being a mudstone with minor amounts of sand and ash. Miocene sediments are composed of grayish olive mud, mudstone, and shale. Limestone clasts, sand, and pebble beds occur toward the bottom of the section, and bioturbation is common. Diatoms were not found below Core 570-36. Sediment dated by shipboard personnel as Eocene consists of silty mud, sand, a nannofossil-rich limestone, and a radiolarian-rich mudstone. A conglomerate rests on the serpentinite basement.

Stratigraphic occurrences of selected diatoms at Site 570 are summarized in Table 6.

The oldest diatomaceous sample, 570-36,CC, contained only one stratigraphically useful species, the lower to upper Miocene Rossiella paleacea. The next notable diatom to occur, going upsection, was Cosciondiscus nodulifer, making its appearance at the base of Core 570-35. Section 570-34,CC contained frequent specimens of the upper Miocene Melosira sulcata var. siberica (Barron, 1974). Cores 570-36 through 570-32 are assigned to the Coscinodiscus yabei Zone. A hiatus representing the Nitzschia porteri and Nitzschia miocenica zones is indicated in Core 570-32 and the lower part of Core 570-31. Sample $570-31-1,47-48 \mathrm{~cm}$ is assigned to the Thalassiosira convexa Zone; the assignment is supported by the first occurrences of Rossiella tatsunokuchiensis and Coscinodiscus temperei var. delicata. The range of C. temperei var. delicata is restricted to the middle and lowermost part of the upper Miocene (Barron, 1981). This T. convexa Zone ranges from the top of Core 570-31 to the top of Core 570-24.

The Nitzschia jouseae Zone is absent, suggesting a hiatus in the upper Pliocene. The marker fossil Rhizoso- 
Table 5. Stratigraphic occurrences of selected diatoms in Holes 569 and 569A.

\begin{tabular}{|c|c|c|c|c|c|c|c|c|c|c|c|c|c|c|c|}
\hline Subseries & $\begin{array}{l}\text { Diatom } \\
\text { zone }\end{array}$ & $\begin{array}{c}\text { Sample } \\
\text { (interval in } \mathrm{cm} \text { ) }\end{array}$ & 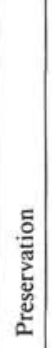 & 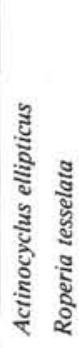 & 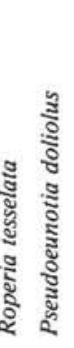 & 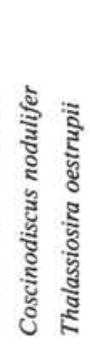 & & 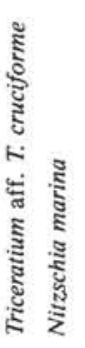 & 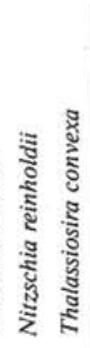 & 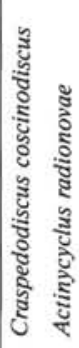 & 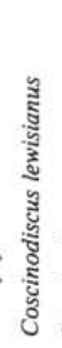 & 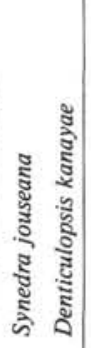 & 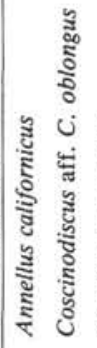 & 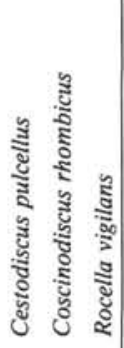 & 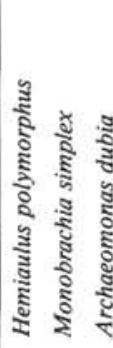 \\
\hline $\begin{array}{c}\text { upper } \\
\text { Pleistocene }\end{array}$ & $\begin{array}{l}\text { Pseudoeunotia } \\
\text { doliolus }\end{array}$ & $\begin{array}{l}\text { Hole 569 } \\
1-1,30-31 \text { and } 31-32 \\
1, C C \\
2-2,30-31 \text { and } 39-40 \\
2-4,30-31 \text { and } 39-40 \\
2, C C \\
3-2,20-21 \text { and } 102-103 \\
3-4,20-21 \\
3-6,102-103 \\
3, C C \\
4-2,41-42 \text { and } 60-61\end{array}$ & $\begin{array}{l}G \\
G \\
P \\
G \\
G \\
G \\
G \\
P \\
P \\
G \\
\end{array}$ & $\begin{array}{ll}\mathrm{R} & \mathrm{R} \\
& \\
& \mathrm{R} \\
& \mathrm{R} \\
& \mathrm{R} \\
& \mathrm{R} \\
& \mathrm{R} \\
\end{array}$ & $\begin{array}{ll}\mathrm{R} & \mathrm{C} \\
& \mathrm{R} \\
& \mathrm{R} \\
\mathrm{R} & \mathrm{C} \\
& \mathrm{C} \\
& \mathrm{C} \\
& \mathrm{C} \\
\mathrm{R} & \mathrm{R} \\
& \mathrm{R} \\
\mathrm{R} & \mathrm{C} \\
\end{array}$ & $\begin{array}{ll}R & C \\
R & C \\
C & C \\
C & C \\
C & C \\
C & C \\
R & \\
R & R \\
C & C\end{array}$ & $\begin{array}{ll}\mathrm{R} & \\
\mathrm{R} & \mathrm{R} \\
\mathrm{R} & \\
\mathrm{F} & \\
& \\
\mathrm{R} & \\
\mathrm{R} & \\
& \\
& \\
\end{array}$ & $\begin{array}{ll}\mathrm{R} & \\
\mathrm{R} \\
\mathrm{R} \\
\mathrm{R} \\
\mathrm{R} \\
\mathrm{R} \\
\mathrm{R}\end{array}$ & & & & & & & \\
\hline $\begin{array}{c}\text { upper Pliocene- } \\
\text { lower } \\
\text { Pleistocene }\end{array}$ & $\begin{array}{l}\text { Nitzschia } \\
\text { reinholdii }\end{array}$ & $\begin{array}{l}4-4,41-42 \text { and } 60-61 \\
4-6,41-42 \\
4, C C \\
5-2,50-51 \text { and } 99-100 \\
5-4,60-61 \\
5, C C \\
6-2,34-35 \\
6-4,34-35 \\
6, C C \\
7-2,54-55 \text { and } 80-81 \\
7-4,80-81\end{array}$ & \begin{tabular}{l|}
$\mathrm{G}$ \\
$\mathrm{M}$ \\
$\mathrm{M}$ \\
$\mathrm{G}$ \\
$\mathrm{M}$ \\
$\mathrm{M}$ \\
$\mathrm{G}$ \\
$\mathrm{P}$ \\
$\mathrm{M}$ \\
$\mathrm{M}$ \\
$\mathrm{P}$
\end{tabular} & $\mathrm{R}^{\mathrm{R}}$ & $\begin{array}{ll}\mathrm{R} & \mathrm{C} \\
\mathrm{F} \\
\mathrm{F} \\
\mathrm{F} \\
\mathrm{R} \\
\mathrm{R} \\
\mathrm{R} \\
\mathrm{R} \\
\mathrm{R}\end{array}$ & $\begin{array}{ll}\mathrm{C} & \mathrm{C} \\
\mathrm{F} & \mathrm{C} \\
\mathrm{F} & \mathrm{F} \\
\mathrm{F} & \mathrm{F} \\
\mathrm{R} & \mathrm{R} \\
\mathrm{R} & \mathrm{R} \\
\mathrm{F} & \mathrm{R} \\
& \mathrm{R} \\
\mathrm{F} & \mathrm{R} \\
\mathrm{R} & \mathrm{F} \\
\mathrm{R} & \mathrm{R}\end{array}$ & R & $\begin{array}{l}\mathrm{R} \\
\mathrm{R} \\
\mathrm{R} \\
\mathrm{R} \\
\mathrm{R} \\
\mathrm{R} \\
\mathrm{R}\end{array}$ & $\begin{array}{l}\mathrm{R} \\
\\
\mathrm{R} \\
\mathrm{R}\end{array}$ & & & & & & \\
\hline $\begin{array}{l}\text { upper Miocene- } \\
\text { lower Pliocene }\end{array}$ & $\begin{array}{l}\text { Thalassiosira } \\
\text { convexa }\end{array}$ & $\begin{array}{l}7, \mathrm{CC} \\
8-1,10-11 \\
8, \mathrm{CC}\end{array}$ & \begin{tabular}{l|}
$\mathrm{P}$ \\
$\mathrm{P}$ \\
$\mathrm{P}$
\end{tabular} & & & R $\quad R$ & & & $\begin{array}{l}\mathrm{F} \\
\mathrm{F} \\
\mathrm{R}\end{array}$ & & & & & & \\
\hline$?$ & Indeterminate & $9-2,8-9$ and $11-12$ & $\mathrm{P}$ & & & R & & & & & & & & & \\
\hline $\begin{array}{l}\text { upper lower- } \\
\text { lower middle } \\
\text { Miocene }\end{array}$ & Indeterminate & $\begin{array}{l}10-2,10-11 \text { and } 41-42 \\
10, C C \\
11-2,20-21 \text { and } 41-42 \\
12-4,40-41 \text { and } 45-46 \\
13-4,4-5 \text { and } 30-31\end{array}$ & $\begin{array}{l}\mathrm{P} \\
\mathrm{M} \\
\mathrm{P} \\
\mathrm{P} \\
\mathrm{P}\end{array}$ & $\mathbf{R}$ & & & & & & $\begin{array}{ll}\mathrm{R} & \mathrm{R} \\
\mathrm{R} & \end{array}$ & $\begin{array}{l}R \\
R \\
R \\
R\end{array}$ & $\begin{array}{ll}R & R \\
& \end{array}$ & $\mathrm{R} \quad \mathrm{R}$ & & \\
\hline $\begin{array}{l}\text { upper Oligocene- } \\
\text { lower Miocene }\end{array}$ & Indeterminate & $\begin{array}{l}23-4,5-6 \text { and } 45-46 \\
25, C C \\
26-2,97-98 \\
27-2,12-13 \text { and } 14-15\end{array}$ & $\begin{array}{l}\mathrm{M} \\
\mathrm{P} \\
\mathrm{M} \\
\mathrm{P}\end{array}$ & & & & & & & $\begin{array}{l}R \\
R \\
R\end{array}$ & R & $\begin{array}{l}\mathrm{R} \\
\mathrm{R}\end{array}$ & R & $\mathrm{R}$ & \\
\hline $\begin{array}{c}\text { upper } \\
\text { Oligocene- } \\
\text { lower Miocene }\end{array}$ & Indeterminate & $\begin{array}{l}\text { Hole 569A } \\
1-2,30-31 \text { and } 39-40 \\
1, C C \\
2, C C\end{array}$ & $\begin{array}{l}\mathrm{M} \\
\mathrm{P} \\
\mathrm{P}\end{array}$ & & & & & & & $\mathbf{R}$ & & & & $\begin{array}{lll}R & R\end{array}$ & \\
\hline Eocene & Indeterminate & $\begin{array}{l}9, \mathrm{CC} \\
11, \mathrm{CC}\end{array}$ & $\begin{array}{l}\mathrm{P} \\
\mathrm{P}\end{array}$ & & & & & & & & & & & & $\begin{array}{lll}\mathrm{R} & \mathrm{R} & \mathrm{R} \\
\mathrm{R} & \mathrm{R} & \mathrm{R}\end{array}$ \\
\hline
\end{tabular}

Note: See Table 1 for explanation of abbreviations.

lenia praebergonii was found only at the base of Core 570-23. The $R$. praebergonii Zone is therefore assigned to the interval from $570-23, \mathrm{CC}$ to $570-23-6,40-41 \mathrm{~cm}$. The Pliocene/Pleistocene boundary should occur somewhere in this interval.

The next diatom zone recognizable in the sediments is the Nitzschia reinholdii Zone, ranging from the first evolutionary appearance of Pseudoeunotia doliolus (570$23-2,50-51 \mathrm{~cm}$ ) to the extinction of $N$. reinholdii (above the base of Core 570-6). The P. doliolus Zone covers the interval from the bottom of Core 570-5 to the top of the hole.

\section{CONCLUSIONS}

The Equatorial Pacific zonations of Burckle (1972, 1977, 1978), Burckle and Trainer (1979), and Barron $(1980,1981,1983)$ are applicable to diatomaceous sediments off southern Guatemala. The limitation to the application of these zonations is the high amount of terrigenous material reducing the number of frustules in any one sample. The observations by Harper et al. (1982), concerning numerous unconformities in this slope area, are reaffirmed by the results of Leg 84 . There were sequences of deposition and erosion in these submarine 
Table 6. Stratigraphic occurrences of selected diatoms in Hole 570.

\begin{tabular}{|c|c|c|c|c|c|c|c|c|c|c|c|c|c|}
\hline Subseries & $\begin{array}{l}\text { Diatom } \\
\text { zone }\end{array}$ & $\begin{array}{c}\text { Sample } \\
\text { (interval in } \mathrm{cm} \text { ) }\end{array}$ & 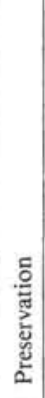 & 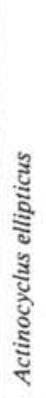 & 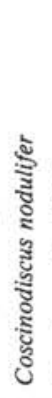 & 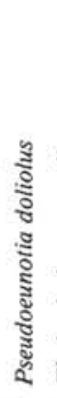 & 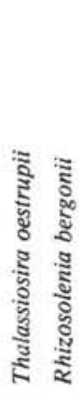 & 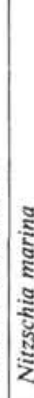 & 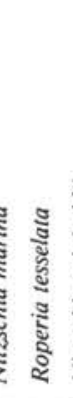 & 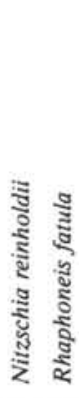 & 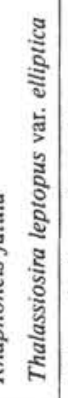 & 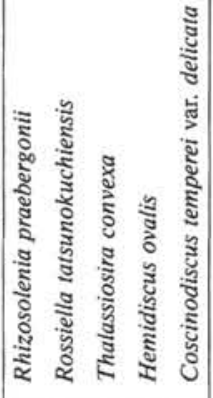 & 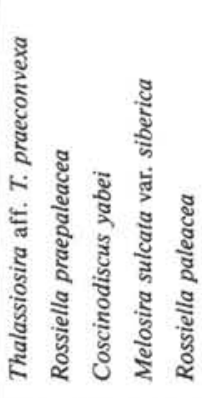 \\
\hline 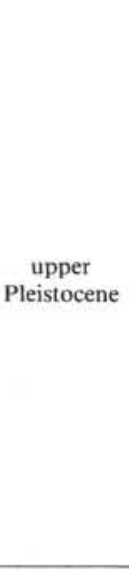 & $\begin{array}{c}\text { Pseudoeunotia } \\
\text { doliolus }\end{array}$ & $\begin{array}{l}1-2,29-30 \\
1-4,1-2 \text { and } 3-4 \\
1, C C \\
2-2,30-31 \text { and } 33-34 \\
2-4,30-31 \text { and } 33-34 \\
2, C C \\
3-2,69-70 \text { and } 72-73 \\
3-4,69-70 \text { and } 72-73 \\
3-6,69-70 \\
3, C C \\
4-2,20-21 \text { and } 22-23 \\
4-4,20-21 \text { and } 22-23 \\
4, C C \\
5-2,41-42 \text { and } 46-47 \\
5-4,41-42 \text { and } 46-47 \\
5-6,41-42 \text { and } 46-47 \\
5, C C \\
6-2,27-28 \text { and } 31-32 \\
6-4,27-28 \text { and } 31-32 \\
6-6,27-28\end{array}$ & $\begin{array}{l}G \\
G \\
G \\
G \\
G \\
G \\
G \\
G \\
P \\
G \\
G \\
G \\
G \\
G \\
G \\
G \\
P \\
G \\
G \\
M\end{array}$ & $\begin{array}{l}\mathrm{R} \\
\\
\mathrm{R} \\
\mathrm{R} \\
\mathrm{R}\end{array}$ & $\begin{array}{l}\mathrm{R} \\
\mathrm{C} \\
\mathrm{R} \\
\mathrm{C} \\
\mathrm{C} \\
\mathrm{R} \\
\mathrm{R} \\
\mathrm{C} \\
\mathrm{R} \\
\mathrm{C} \\
\mathrm{R} \\
\mathrm{R} \\
\mathrm{R} \\
\mathrm{R} \\
\mathrm{R} \\
\mathrm{R}\end{array}$ & $\begin{array}{l}R \\
R \\
R \\
R \\
F \\
R \\
R \\
R \\
R \\
R \\
R \\
R \\
R \\
R \\
R \\
R \\
R \\
\\
R\end{array}$ & $\begin{array}{ll}\mathrm{R} & \\
\mathrm{C} & \mathrm{R} \\
\mathrm{C} & \mathrm{R} \\
\mathrm{R} & \\
\mathrm{C} & \\
\mathrm{R} & \\
\mathrm{R} & \\
\mathrm{R} & \\
\mathrm{F} & \\
\mathrm{R} & \mathrm{R} \\
\mathrm{R} & \\
\mathrm{R} & \mathrm{R} \\
\mathrm{R} & \mathrm{R} \\
\mathrm{R} & \\
\mathrm{R} & \mathrm{R} \\
\mathrm{R} & \mathrm{R} \\
\mathrm{R} & \\
\mathrm{R} & \mathrm{R} \\
\mathrm{R} & \mathrm{R} \\
\mathrm{R} & \mathrm{R} \\
\end{array}$ & $\begin{array}{l}\mathrm{R} \\
\mathrm{R} \\
\mathrm{R}\end{array}$ & $\begin{array}{ll}R & R \\
& R \\
R & \\
R & \\
R & \\
R & \\
\end{array}$ & & & & \\
\hline $\begin{array}{c}\text { lower } \\
\text { Pleistocene }\end{array}$ & $\begin{array}{l}\text { Nitzschia } \\
\text { reinholdii }\end{array}$ & $\begin{array}{l}6, C C \\
7-2,40-41 \text { and } 44-45 \\
7-4,42-43 \text { and } 45-46 \\
7, C C \\
8-2,30-31 \text { and } 33-34 \\
8, C C \\
9-2,29-30 \text { and } 31-32 \\
9, C C \\
10-1,82-83 \\
10-2,23-24 \\
10, C C \\
11-1,10-11 \\
11-2,32-33 \\
11-3,10-11 \\
11-4,15-16 \\
11, C C \\
14-2,27-28 \text { and } 40-41 \\
14-4,27-28 \text { and } 40-41 \\
14-6,27-28 \\
14, C C \\
15-2,50-51 \text { and } 70-71 \\
15-4,50-51 \text { and } 70-71 \\
15, C C \\
16-2,58-59 \text { and } 116-117 \\
16-4,58-59 \text { and } 116-117 \\
16, C C \\
17-1,33-34 \\
17-2,23-24 \\
17-3,33-34 \\
17-4,23-24 \\
17, C C \\
18-2,30-31 \text { and } 42-43 \\
18, C C \\
19-1,32-33 \\
19-2,19-20 \\
19, C C \\
20-2,7-8 \text { and } 13-14 \\
20, C C \\
21-2,44-45 \text { and } 86-87 \\
21, C C \\
22-2,14-15 \text { and } 37-38 \\
22, C C \\
23-2,40-41 \text { and } 50-51\end{array}$ & $\begin{array}{l}\text { M } \\
G \\
G \\
G \\
G \\
G \\
G \\
G \\
M \\
G \\
G \\
M \\
G \\
M \\
G \\
P \\
\text { G } \\
G \\
M \\
M \\
G \\
G \\
M \\
G \\
G \\
G \\
P \\
M \\
P \\
M \\
M \\
M \\
P \\
M \\
M \\
M \\
M \\
M \\
M \\
G \\
P \\
G \\
P \\
G\end{array}$ & $\begin{array}{l}R \\
F \\
F\end{array}$ & $\begin{array}{l}\mathrm{R} \\
\mathrm{R} \\
\mathrm{R} \\
\mathrm{R} \\
\mathrm{R} \\
\mathrm{R} \\
\mathrm{R} \\
\mathrm{C} \\
\mathrm{R} \\
\mathrm{R} \\
\mathrm{R} \\
\mathrm{R} \\
\mathrm{R} \\
\mathrm{F} \\
\mathrm{R} \\
\\
\mathrm{R} \\
\mathrm{C} \\
\mathrm{R} \\
\mathrm{F} \\
\mathrm{R} \\
\mathrm{F} \\
\\
\mathrm{R} \\
\mathrm{R} \\
\mathrm{R} \\
\mathrm{R} \\
\mathrm{C} \\
\mathrm{C} \\
\mathrm{R} \\
\mathrm{C}\end{array}$ & 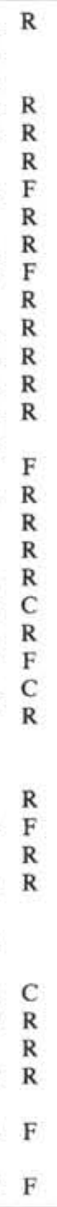 & 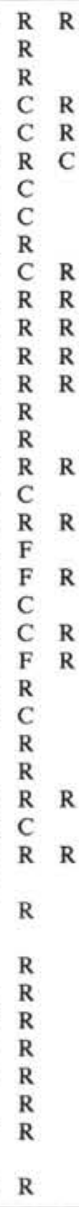 & $\begin{array}{l}\mathrm{R} \\
\mathrm{R} \\
\mathrm{R} \\
\mathrm{R} \\
\mathrm{R} \\
\mathrm{R} \\
\mathrm{R} \\
\mathrm{C} \\
\mathrm{R} \\
\mathrm{R} \\
\mathrm{R} \\
\mathrm{C} \\
\mathrm{R} \\
\mathrm{R} \\
\mathrm{F}\end{array}$ & $\begin{array}{ll}\mathrm{R} \\
\mathrm{R} \\
\mathrm{R} \\
\mathrm{R} \\
\mathrm{R} \\
\mathrm{R} \\
\mathrm{R} \\
\mathrm{R} \\
\mathrm{R} \\
\mathrm{R} \\
\mathrm{R} \\
\mathrm{R} \\
\mathrm{R} \\
\mathrm{R}\end{array}$ & $\begin{array}{ll}\mathrm{R} & \\
\mathrm{R} & \\
& \\
\mathrm{R} & \\
\mathrm{R} & \\
& \\
\mathrm{R} & \\
\mathrm{R} & \mathrm{R}\end{array}$ & $\begin{array}{l}R \\
R \\
R \\
\\
R\end{array}$ & $\mathbf{R}$ & \\
\hline
\end{tabular}


Table 6. (Continued).

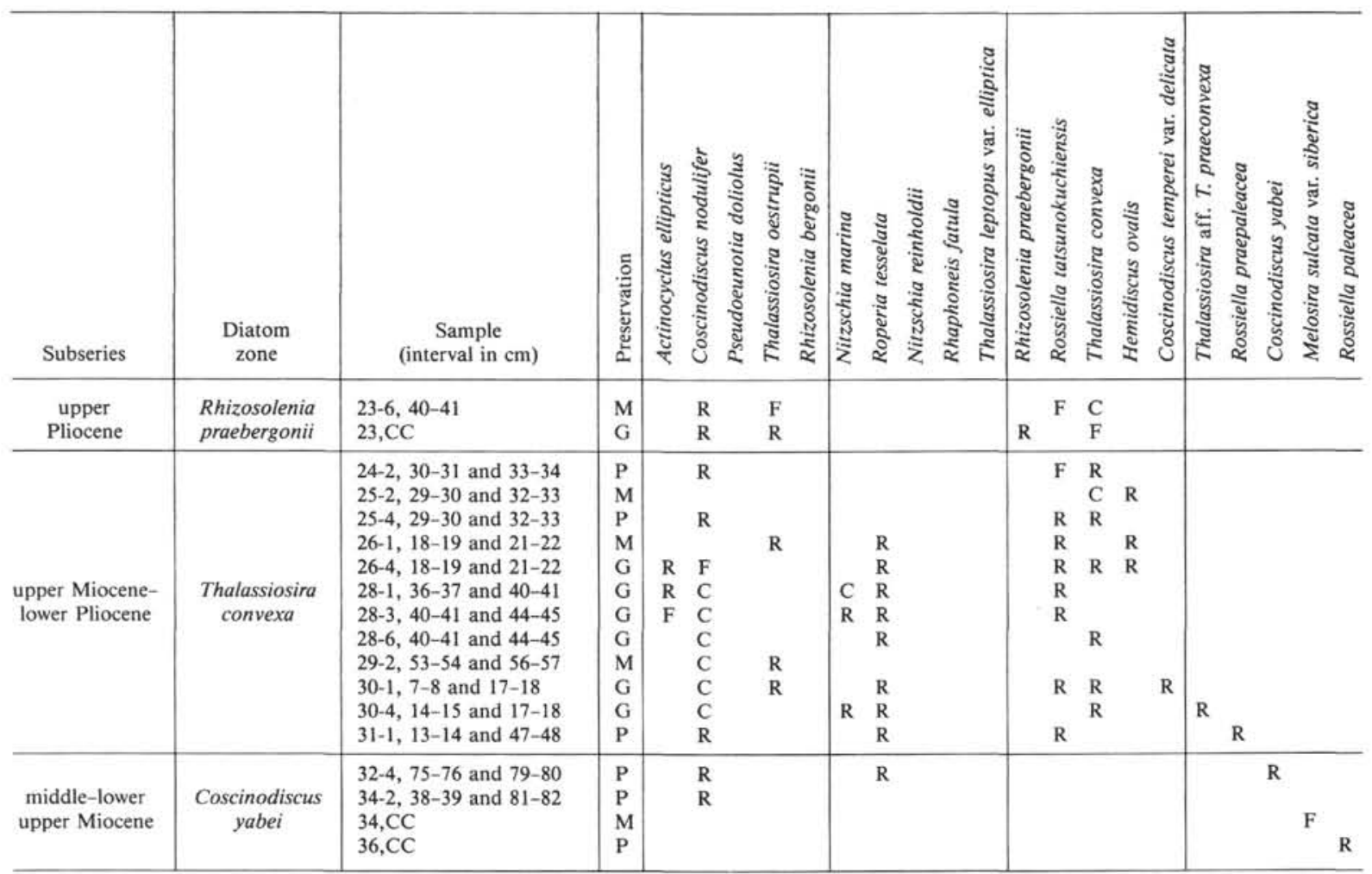

Note: See Table 1 for explanation of abbreviations.

canyon sites with fluctuating amounts of terrigenous input, including freshwater diatoms. The high abundance of nonmarine diatoms was noted by Harper et al. (1982) in their study of Site 497 (same location as Site 569), especially in the upper part of the section. Other limiting factors are the amount of reworking, the sedimentary hiatuses, and the deep water in which the sediments were deposited. Although basement was penetrated at four of the sites on Leg 84 , the sediment immediately above it is Pliocene at Site 566, Cretaceous at 567, and Eocene at 569 and 570.

No diatom zones can be recognized with confidence below the middle Miocene, although Eocene and Oligocene taxa were observed. Barron's $(1981,1983)$ zonation for the lower and middle Miocene can be applied tentatively to this material, bearing in mind that the occurrence of these species in rare numbers could be the result of reworking. The presence of unconformities in the stratigraphic section is implied by the absence of certain eastern equatorial Pacific diatom zones and the poor representation of others. Much of the Pliocene and upper Miocene appear to be absent in this area.

The studies of Hajos (1975), Jousé (1974), and Schrader and Fenner (1976) were used as taxonomic references for the Eocene and Oligocene species.

Further investigations might include more extensive taxonomic studies and frustule size measurements to define specific diatom assemblages indicative of specific climatic and geochemical regimes. This would be particularly applicable in further defining the Pleistocene in- terval, where there are sufficient numbers and species of diatoms present in the core samples.

\section{ACKNOWLEDGMENTS}

The senior author is grateful to the Deep Sea Drilling Project for the opportunity to participate in the shipboard drilling. Additional thanks are due the intrepid Leg $84 \mathrm{crew}$, who collected the many additional samples that were forwarded to the authors for shore-based analyses. John Barron, U.S. Geological Survey, Menlo Park, California, and Lloyd Burckle, Lamont-Doherty Geological Observatory, reviewed the manuscript and provided valuable suggestions and taxonomic assistance. Special thanks go to Dr. Burckle for his generous hospitality in making his time and reference material available. Thanks are also due Jonathan Rider, for his encouragement, and Bernie Siben, for typing the manuscript. Additional support for this research was provided by a grant from Espey, Huston, \& Associates, Inc.

\section{REFERENCES}

Barron, J. A., 1974. The late Miocene-early Pliocene marine diatom assemblage of Southern California-biostratigraphy and paleoecology [Ph.D. dissertation]. University of California, Los Angeles. 1980. Upper Pliocene and Quaternary diatom biostratigraphy of Deep Sea Drilling Project Leg 54, tropical eastern Pacific. In Rosendahl, B. R., Hekinian, R., et al., Init. Repts. DSDP, 54: Washington (U.S. Govt. Printing Office), 455-485. ,1981. Middle Miocene diatom biostratigraphy of DSDP Site 77B in the eastern equatorial Pacific. Geosci. J., 2 (2):137-144. 1983. Latest Oligocene through early middle Miocene diatom biostratigraphy of the tropical Pacific. Mar. Micropaleontol., $7: 487-515$.

Burckle, L. H., 1972. Late Cenozoic planktonic diatom zones from the eastern equatorial Pacific. Nova Hedwigia Beih., 39:217-246. , 1977. Pliocene and Pleistocene diatom datum levels from the equatorial Pacific. Ouat. Res., 7:330-340.

1978. Early Miocene to Pliocene diatom datum levels for the equatorial Pacific. Proc. Indonesian Neog. Symp. Republic of 
Indonesia Ministry of Mines and Energy Spec. Publ., (Geological Research and Development Centre), 1:25-44.

Burckle, L. H., Hammond, S. R., and Seyb, S. M., 1978. A stratigraphically important new datum from the Pleistocene of the North Pacific. Pacific Sci., 32(2):209-214.

Burckle, L. H., and Trainer, J., 1979. Middle and late Pliocene diatom datum levels from the central Pacific. Micropaleontology, 25(3): 281-293.

Hajos, M., 1975. Late Cretaceous Archaeomonadaceae, Diatomaceae, and Silicoflagellata from the South Pacific Ocean, Deep Sea Drilling Project, Leg 29, Site 275. In Kennett, J. P., Houtz, R. E., et al., Init. Repts. DSDP, 29: Washington (U.S. Govt. Printing Office), 913-1009.

Harper, H. E., Jr., Rider, J. R., and Abbott, W. H., 1982. Diatom biostratigraphy of Sites 495, 496 and 497, Deep Sea Drilling Project Leg 67. In Aubouin J., von Huene, R., et al., Init. Repts. $D S D P, 67$ : Washington (U.S. Govt. Printing Office), 447-454.

Jousé, A. 1974. Diatoms in the Oligocene-Miocene biostratigraphic zones of the tropical areas of the Pacific Ocean. Nova Hedwegia Beih., 45:333-364.

Schrader, H. J., and Fenner, J., 1976. Norwegian Sea Cenozoic diatom biostratigraphy and taxonomy. Part 1 , Norwegian Sea Cenozoic diatom biostratigraphy. In Talwani, M., Udintsev, G., et al., Init. Repts. DSDP, 38: Washington (U.S. Govt. Printing Office), 921-1099.

\section{APPENDIX}

\section{Diatom and Related Taxa Referenced in This Chapter}

Actinocyclus ellipticus Grunow

A. ellipticus var. javanicus Reinhold

$A$. ingens Rattray

A. octonarius Ehrenberg

A. radionovae Barron

Actinoptychus splendens Ralfs

Archaeomonas dubia Deflandre

Annellus californicus Tempère

Asterolampara praemarylandica Jousé

Asteromphalus imbricatus Wallich

A. arachne (Brébisson) Ralfs

A. elegans Greville

Caloneis westii (Smith) Hendy

Cestodiscus peplum Brun

C. pulcellus Greville

Coscinodiscus crenulatus Grunow

C. lewisianus Greville

C. marginatus Ehrenberg

C. aff. C. nodulifer Schmidt

C. oblongus Greville

C. oligocenicus Jousé

C. plicatus Grunow

C. rhombicus Castracane

C. tabularis var. egregius (Rattray) Hustedt
C. temperei var. delicata Barron

C. yabei Kanaya

Craspedodiscus coscinodiscus Ehrenberg

C. molleri Schmidt

C. rydei Barron

Cyclotella stylorum Brightwell

Cymatogonia amblyoceras Hanna

Denticulopsis kanayae Akiba

D. nicobaria (Grunow) Simonsen

Ethmodiscus rex (Rattray) Hendey

Goniothecium odontella Ehrenberg

Grammatophora marina (Lyngbye) Kützing

Hemidiscus cuneiformis Wallich

Hemidiscus aff. $H$. ovalis Lohman

$H$. polymorphus Grunow

Mastogloia splendida (Gregory) Cleve and Moller

Melosira granulata (Ehrenberg) Ralfs

$M$. sulcata var. siberica Grunow

Monbrachia simplex Schrader

Nitzschia aff. N. apiculata (Gregory) Grunow

$N$. aff. $N$. fossilis (Frenguelli) Kanaya

$N$. jouseae Burckle

N. marina Grunow

N. miocenica Burckle

$N$. reinholdii Kanaya and Koizumi

Paralia sulcata (Ehrenberg) Cleve

Plagiogramma staurophorum (Gregory) Heiberg

Porpeia quadriceps Bailey

Pseudoeunotia doliolus (Wallich) Grunow

Rhaphoneis fatula Lohman

Rhizosolenia bergonii Pergallo

$R$. matuyami Burckle

$R$. miocenica Schrader

$R$. praebergonii Muchina

Rocella vigilans (Schmidt)

Roperia tesselata Heiden et Kolbe

Rossiella paleacea (Grunow) Jousé

$R$. praepaleacea (Schrader) Jousé

$R$. tatsunokuchiensis Koizumi

$R$. veniamini Jousé

Stephanopyxis grunowii Grove et Stuart

Stictodiscus trigonus Castracane

Synedra jouseana Sheshukova-Poretzkaya

Thalassionema nitzschiodes Grunow

Thalassiosira convexa Muchina

$T$. excentrica (Ehrenberg) Cleve

T. leptopus var. elliptica (Kolbe) Barron

T. oestrupii (Ostenfeld) Proshkina-Lavrenko

$T$. aff. T. praeconvexa Burckle

Triceratium cinnamomeum Greville

T. cinnamomeum var. minor (Grunow) Hasle

$T$. aff. T. cruciforme Schmidt

Trinacria excavata Heiberg 


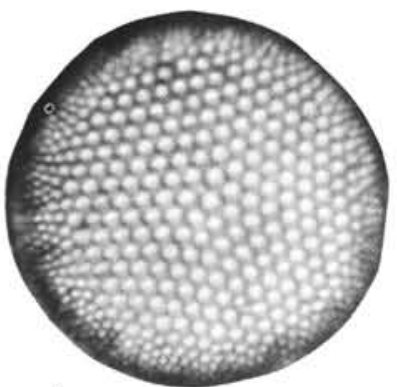

1
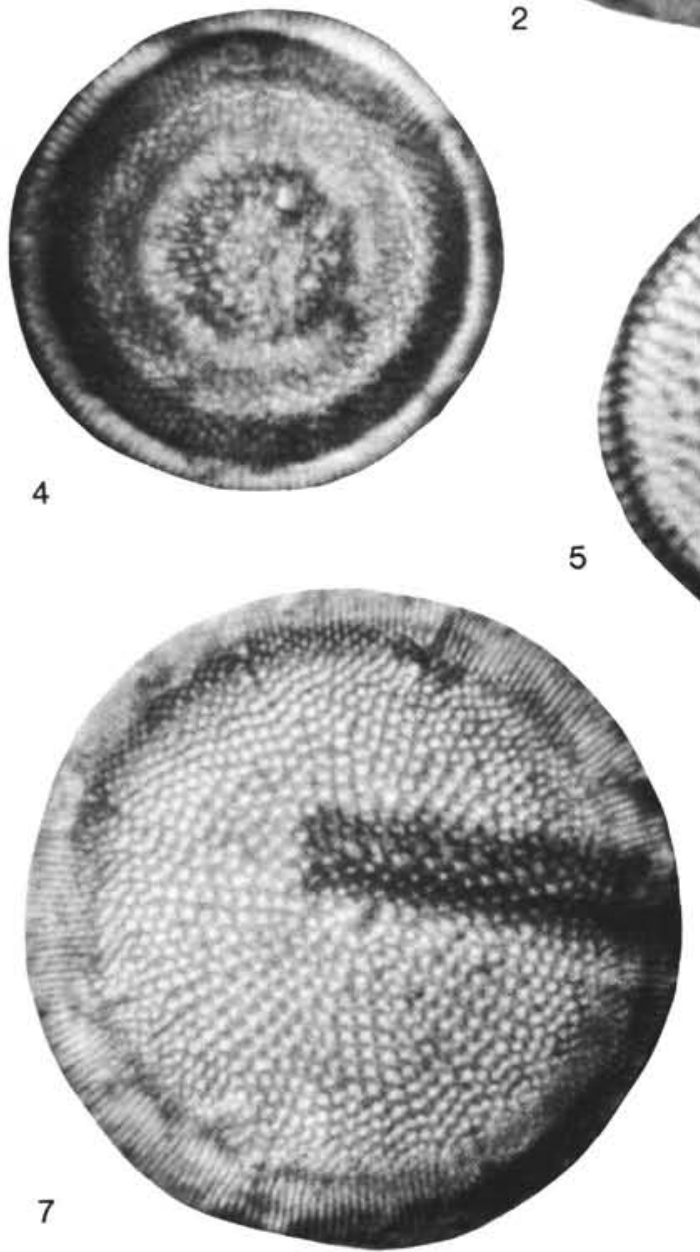

5
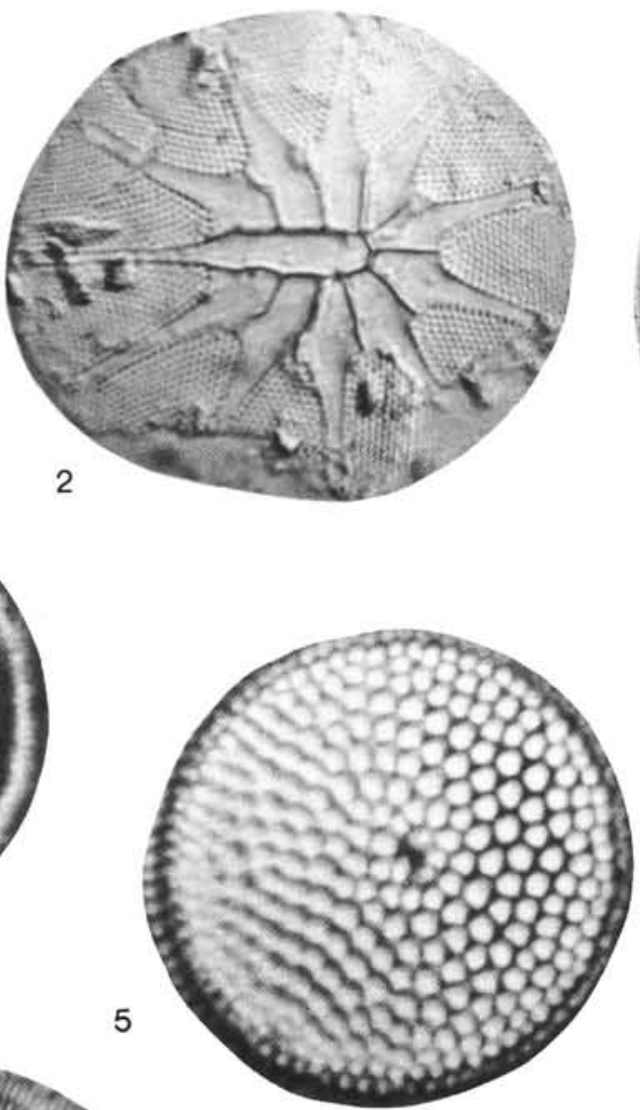
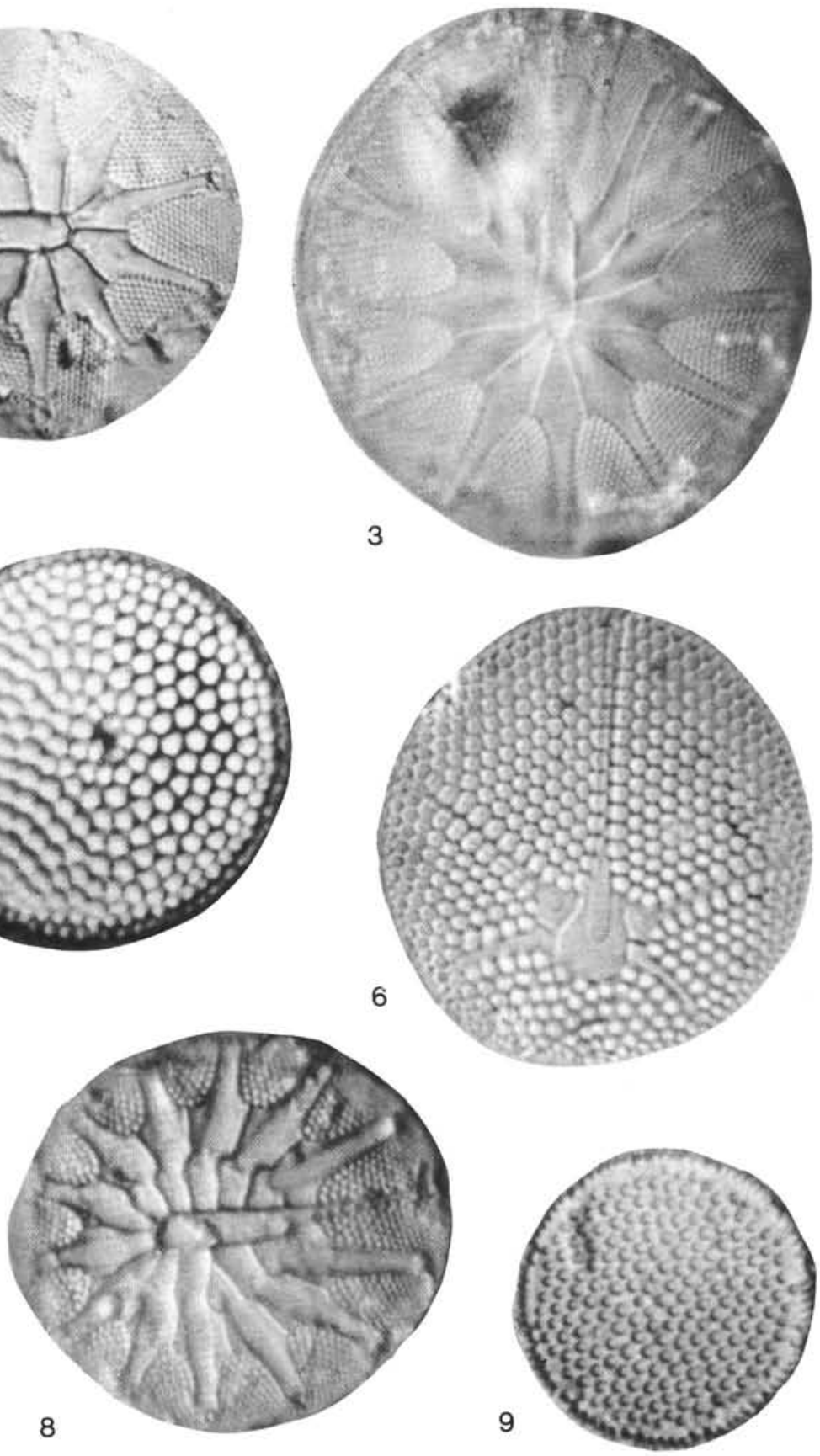

Plate 1. 1. Thalassiosira sp., Sample $565-2-3,70-71 \mathrm{~cm}, \times 2000$. 2-3. Asteromphalus imbricatus Wallich, $\times 1280,(2)$ Sample $568-7-4,52-53 \mathrm{~cm}$, (3) Sample 568-2-4, 137-138 cm. 4. Cestodiscus pulcellus Greville, Sample 569-13-14, 30-31 cm, $\times 1280$. 5. Coscinodiscus nodulifer Schmidt, Sample $568-2-4,137-138 \mathrm{~cm}, \times 1280$. 6. Asteromphalus arachne (Brébisson) Ralfs, Sample $568-8-1,8-9 \mathrm{~cm}, \times 2020$. 7. Actinocyclus octonarius Ehrenberg, Sample 565-2-3, 70-71 cm, $\times 2000$. 8. Asteromphalus elegans Greville, Sample 566-2-4, 14-15 cm, $\times 1280$. 9. Coscinodiscus tabularis var. egregius (Rattray) Hustedt, Sample 566-2-3, 14-15 cm, $\times 2020$. 


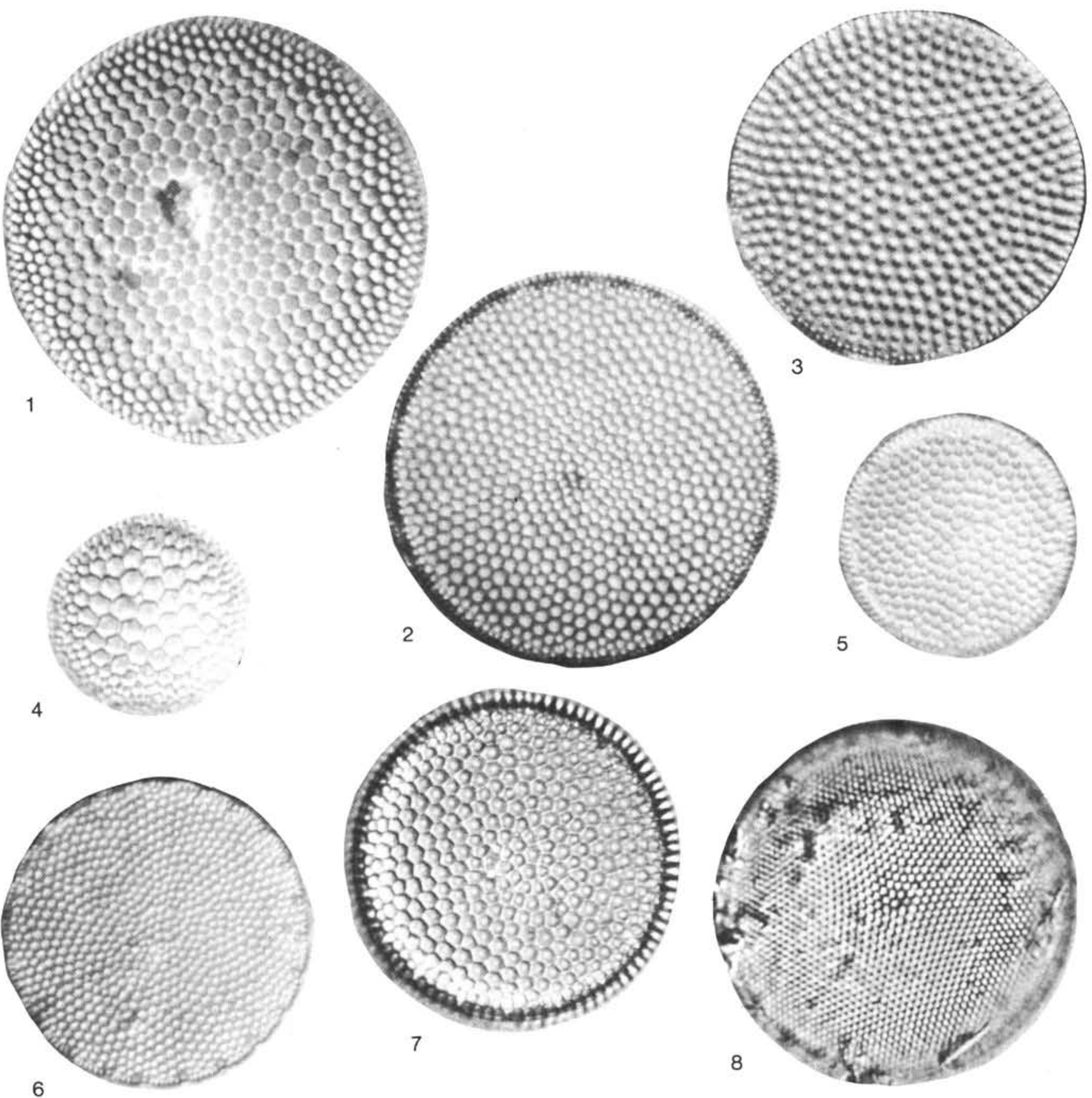

Plate 2. 1. Roperia tesselata (Roper) Grunow, Sample 568-15-4, 73-74 cm, $\times 2020$. 2. Coscinodiscus nodulifer Schmidt, Sample 566-1-2, 22-23 cm, $\times 800$. 3. Thalassiosira or Coscinodiscus sp., Sample $565-2-3,70-71 \mathrm{~cm}, \times 2000$. 4. Thalassiosira oestrupii (Ostenfeld) Proshkina-Lavrenko, Sample $565-2-3,70-71 \mathrm{~cm}, \times 2000$. 5. Coscinodiscus tabularis var. egregius (Rattray) Hustedt, Sample 568-2-4, 13-14 cm, $\times 2020$. 6. Coscinodiscus crenulatus Grunow, Sample 570-2-4, 33-34 cm, $\times 1280$. 7. Coscinodiscus nodulifer Schmidt, Sample 565-1-1, 24-24 cm, $\times 1260.8$. Thalassiosira excentrica (Ehrenberg) Cleve, Sample 565-2-3, 70-71 cm, $\times 2000$. 

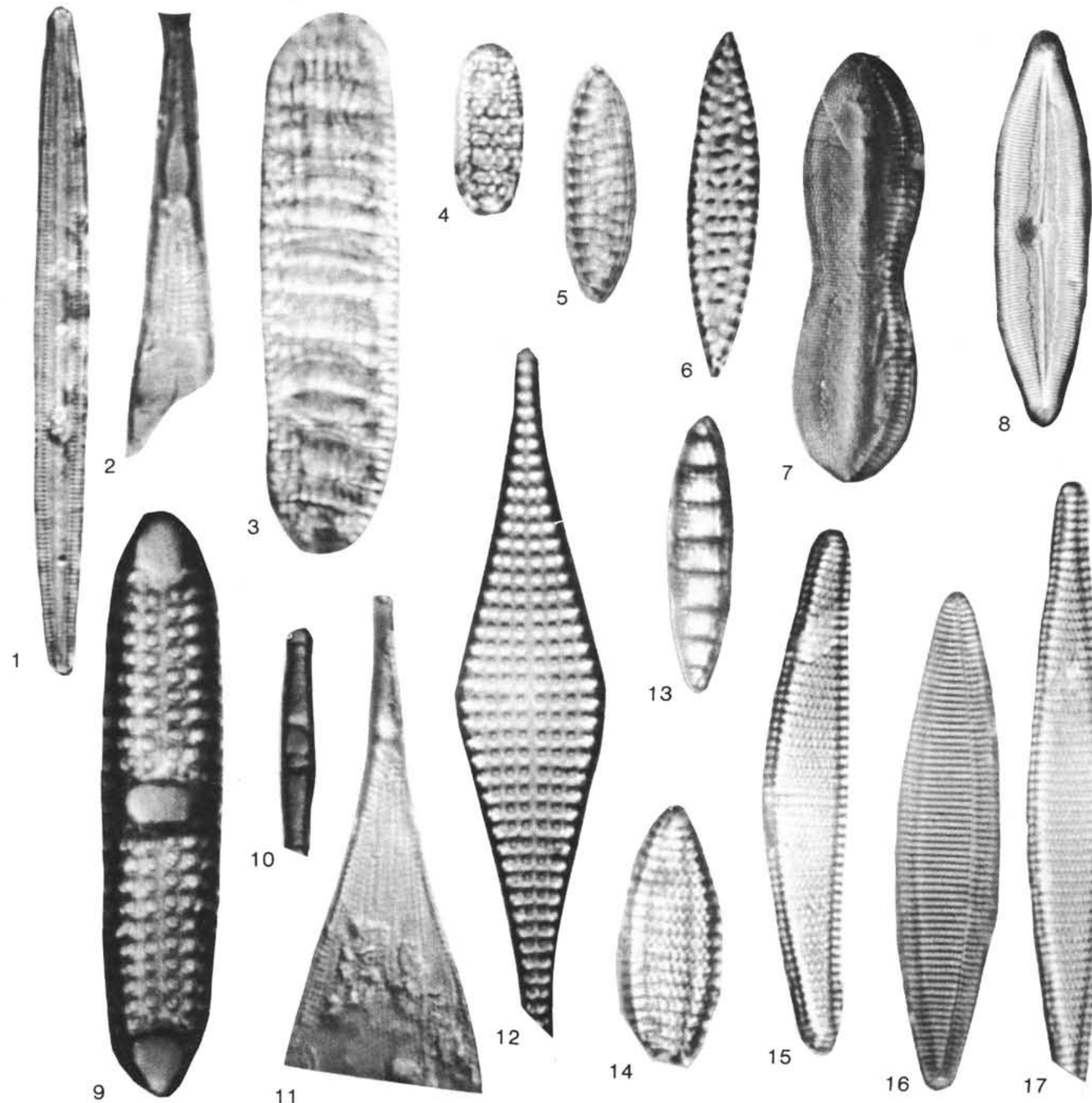

Plate 3. 1. Synedra jouseana Sheshukova-Poretzkaya, Sample $568-26-4,45-46 \mathrm{~cm}, \times 1280$. 2, 11. Rhizosolenia bergonii Peragallo, $\times 2020$, (2) Sample 566-2-3, 14-15 cm, (11) Sample 568-2-4, 137-138 cm. 3. Denticulopsis kanayae Akiba, Sample 568-24-2, 79-80 cm, $\times 2020$. 5. Rossiella tatsunokuchiensis (Koizumi) Jousé, Sample 570-28-1, 40-41 cm, $\times 2020$. 6. Rossiella praepaleacea Schrader, Sample 568-24-2, 79-80 cm, $\times 2020$. 7. Nitzschia aff. N. apiculata (Gregory) Grunow, Sample $570-14-4,40-41 \mathrm{~cm}, \times 800$. 8. Caloneis westii (Smith) Hendey, Sample 565-1-4, 70-71 cm, $\times 800$. 9. Plagiogramma staurophorum (Gregory) Heiberg, Sample 570-15-2, 50-51 cm, $\times 1280$. 10. Grammatophora marina (Lyngbye) Kutzing, Sample $570-14-4,40-41 \mathrm{~cm}, \times 800$. 12. Raphoneis sp., Sample $568-18-4,27-28 \mathrm{~cm}, \times 2020$. 13. Denticulopsis sp., Sample 567A-2-2, 71-72 cm, $\times 2020$. 14. Nitzschia miocenica Burckle, Sample $567 \mathrm{~A}-2-2,71-72 \mathrm{~cm}, \times 2020$. 15. Pseudoeunotia doliolus (Wallich) Grunow, Sample 565-2-3, 70-71 cm, $\times 2020$. 16. Nitzschia reinholdii Kanaya et Koizumi, Sample 570-21-2, 86-87 cm, $\times 1024.17$. Nitzschia aff. N. fossils (Frenguelli) Kanaya, Sample 570-22-2, 37-38 cm, $\times 2020$. 


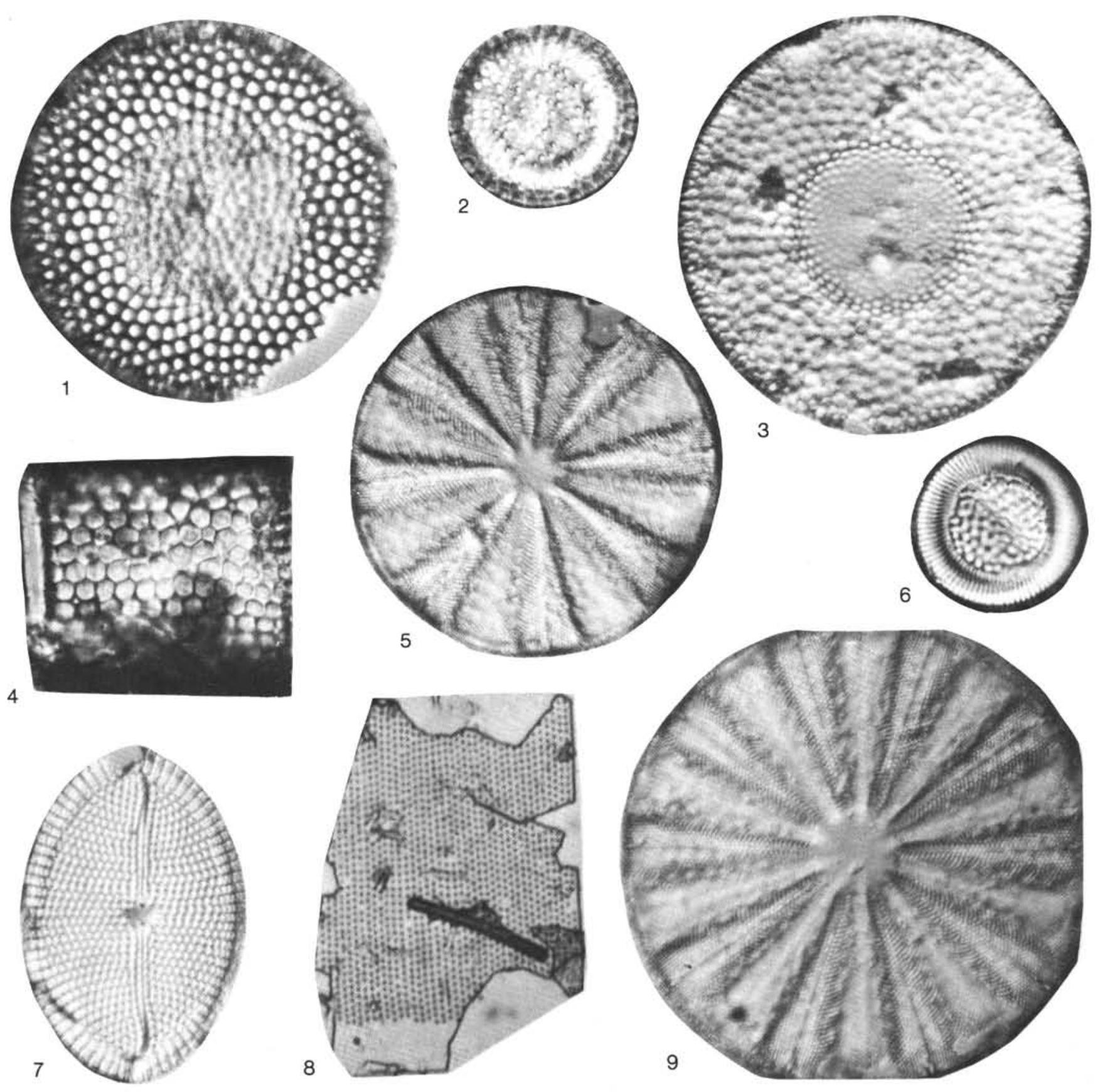

Plate 4. 1. Craspedodiscus aff. C. coscinodiscus Ehrenberg, Sample 569A-2-1, 39-40 cm, $\times 800$. 2. Melosira sp., Sample 567A-2-2, 71-72 cm, $\times 1260$. 3. Craspedodiscus coscinodiscus Ehrenberg, Sample 568-24-2, 79-80, $\times 800$. 4. Annellus californicus Tempère, Sample 568-24-2, 79-80 cm, $\times 1260$. 5, 9. Actinoptychus splendens (Shadbolt) Ralfs, $\times 800$ (5) Sample 570-15-4, 50-51 cm, (9) Sample 570-15-4, 50-51 cm. 6. Cyclotella stylorum Brightwell, Sample $565-1-2,52-53 \mathrm{~cm}, \times 1260$. 7. Mastogloia splendida (Gregory) Cleve et Moller, Sample 570-30-4, $14-15 \mathrm{~cm}, \times 800$. 8. Ethmodiscus rex (Wallich) Hendey, Sample 567A-1-4, 47-48 cm, $\times 512$. 

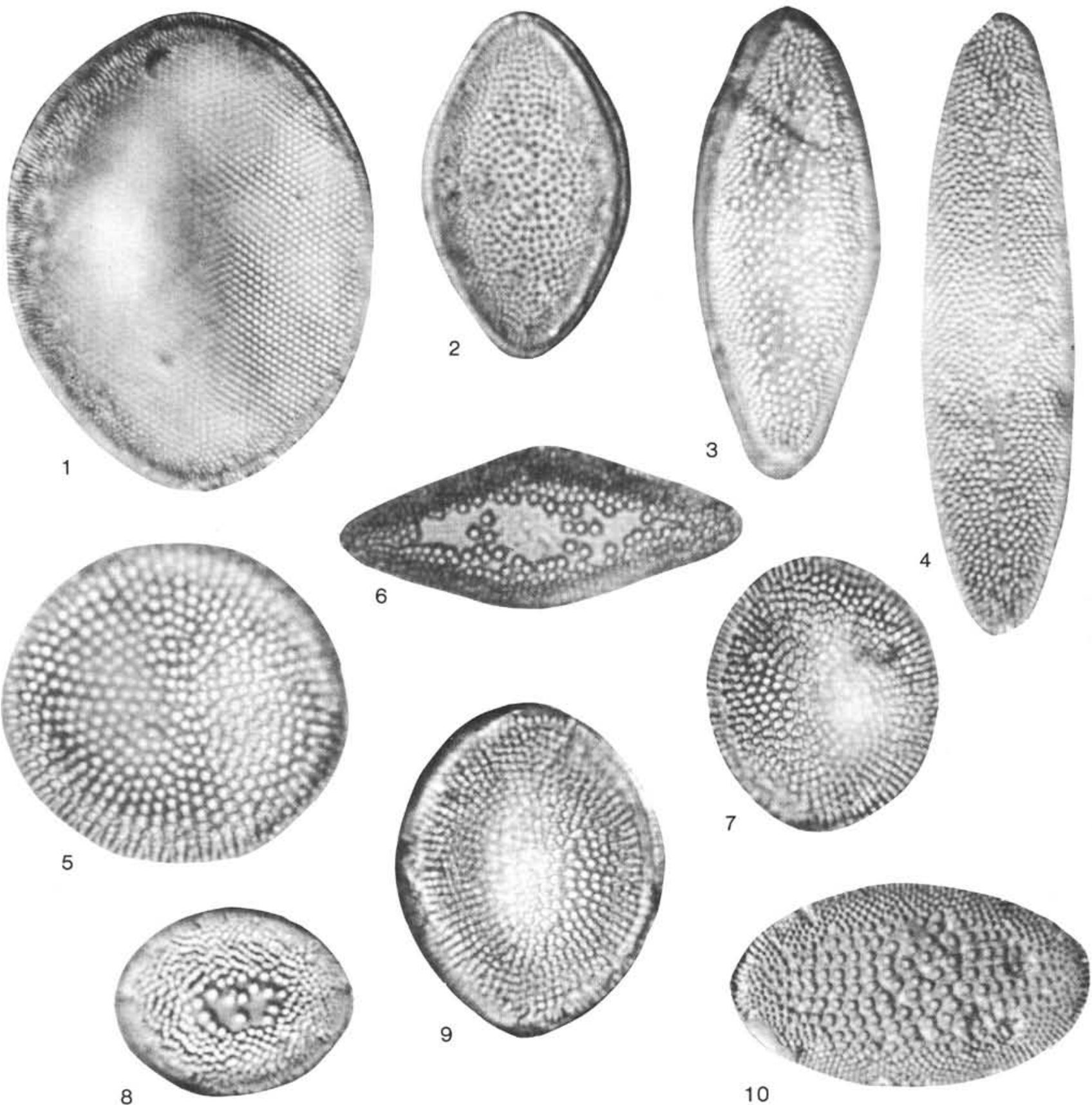

Plate 5. 1. Thalassiosira leptopus var. elliptica (Kolbe) Barron, Sample $569-4-2,60-61 \mathrm{~cm}, \times 800$. 2. Actinocyclus ellipticus var. javanicus Reinhold, Sample 568-27-2, 35-36 cm, $\times 1280$. 3, 4. Actinocyclus ellipticus Grunow, (3) Sample 566-4-2, 48-49 cm, $\times 1280$, (4) Sample 570-22-2, $37-38 \mathrm{~cm}, \times 2020$. 5. Coscinodiscus plicatus Grunow, Sample 568-27-2, 35-36 cm, $\times 1280$. 6. Cestodiscus peplum Brun, Sample 568-35-2, 5-6 cm, $\times 1280$. 7, 9. Coscinodiscus temperei var. delicata Barron, $\times 2020$, (7) Sample 570-31-1, 13-14 cm, (9) Sample 570-31-1, 13-14 cm. 8. Hemidiscus ovalis Lohman, Sample $568-27-2,35-36 \mathrm{~cm}, \times 2020.10$. Coscinodiscus lewisianus Greville, Sample 569-10-2, 10-11 cm, $\times 1280$. 


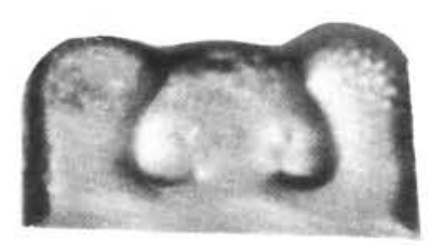

1

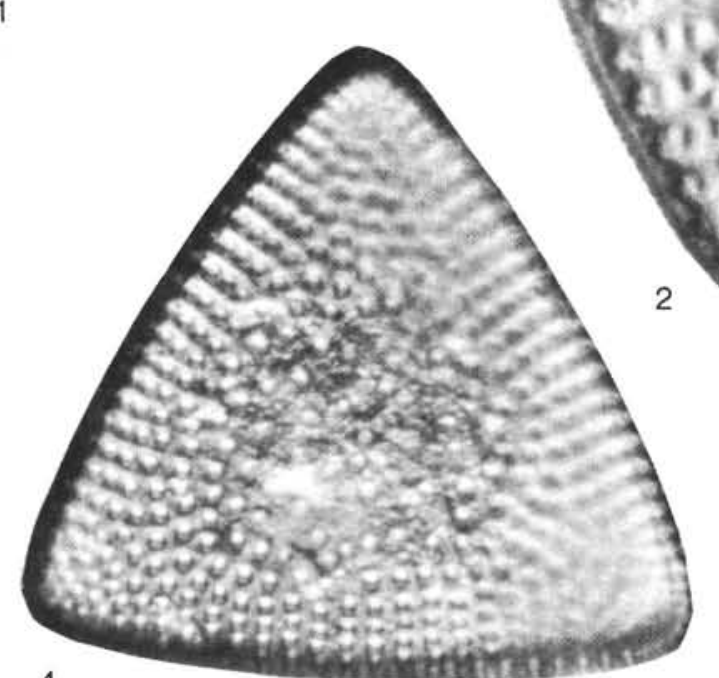

4

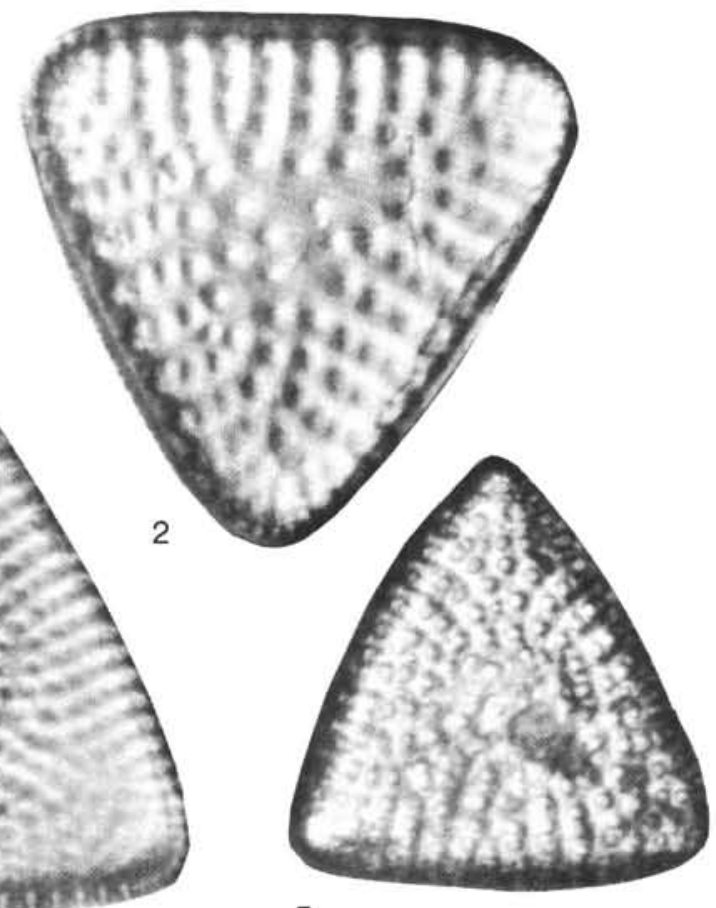

5
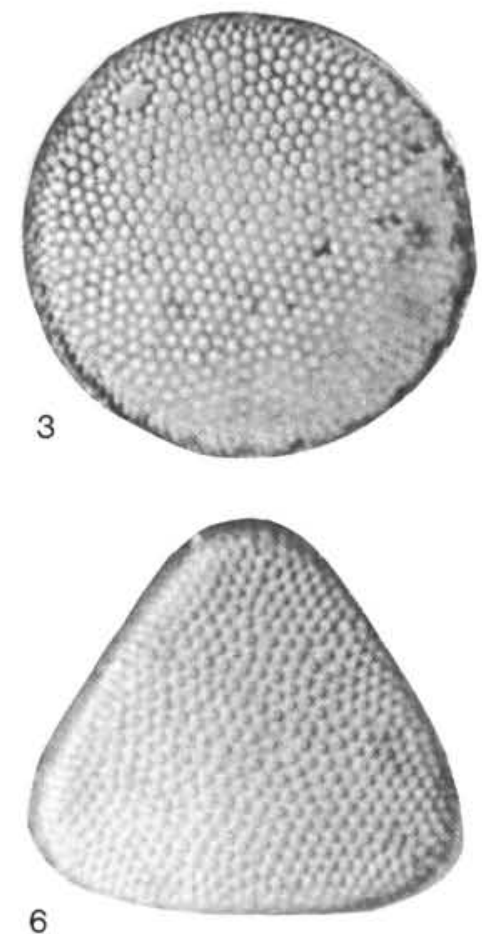

6

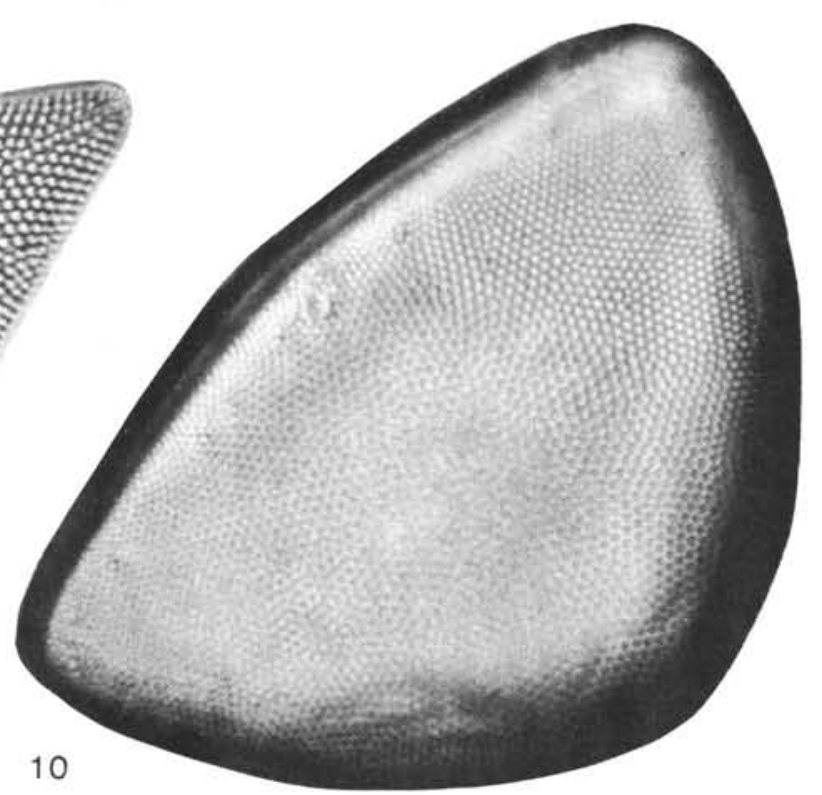

Plate 6. 1. Porpeia quadriceps Bailey, Sample $570-15-4,50-51 \mathrm{~cm}, \times 1280 . \quad 2,4,5$. Stictodiscus trigonus Castracane, (2) Sample 566-2-4, 14-15 cm, $\times 1280$, (4) Sample 569-17-4, 54-55 cm, $\times 800$, (5) Sample 565-25-2, 30-31 cm, $\times 1280$. 3. Roperia tesselata Heiden et Kolbe, Sample 565-1-1, $24-25 \mathrm{~cm}, \times 1260$. 6. Triceratium cinnamomeum var. minor (Grunow) Hasle, Sample $568-2-2,136-137 \mathrm{~cm}, \times 2020$. 7. Cyclotella sp., Sample 565-20-2, 38-39 cm, $\times 1280$. 8, 9. Triceratium cinnamomeum Grevilie, (8) Sample 566-2-3, 14-15 cm, $\times 2020$, (9) Sample 568-24-2, 79-80, $\times 1260$. 10. Hemidiscus cuneiformis Wallich, Sample $565-1-2,52-53 \mathrm{~cm}, \times 1260$. 